\begin{tabular}{l|l|l} 
Geologische Rundschau 81/3 & 695-716 & Stuttgart 1992
\end{tabular}

\title{
Gravity-flow dominated sedimentation on the Buda paleoslope (Hungary): Record of Late Eocene continental escape of the Bakony unit
}

\author{
By L. Fodor, A. MAGYARI, M. KÁzMÉr and A. FogaraSi, Budapest*) \\ With 15 figures
}

\section{Zusammenfassung}

Die obereozäne Folge der Budaer Berge wird aus fluviatilen und Abtragungskonglomeraten, Sandsteinen, bioklastischen Flachwasserkalken, Mergelgesteinen sowie pelagischen Globigerina-Mergeln aufgebaut. Die Abfolge weist eine rapide, im gesamten Gebiet vonstatten gehende Absenkung von kontinentaler Entwicklung bis zu bathyalen Tiefen nach.

Die Sedimentation tritt auf Paläoabhängen an den Flanken von synsedimentären Antiklinalen auf Gesteinen des Basements auf. Die Hebung der Antiklinalen verursachte eine progressive Kippung der Sedimente eine schichtparallele Dehnung, durch Boudinage und Verwerfungen und induzierte eine Umlagerung durch Massenströme. Die Antiklinalen sind staffelförmig in der rechtsdrehenden Scherzone von Budaörs und in der verschuppten Brandungssäule von Buda angeordnet, die die Verwerfung begleiten. Die Zone von Buda korrespondiert zu einem SE-vergenten komplexen Abhang. Es liegt eine Unterlagerung von antithetischen Blindverwerfungen vor, die vermutlich in geringer Tiefe in eine Abscherungsverwerfung Übergeht. Alle Strukturen wurden durch WNW-ESE gerichtete Kompressionen und NNE-SSW orientierte Dehnungen geformt.

Die Einheit des Bakony war während der $\mathrm{Ab}-$ trennung von den Alpen umgrenzt durch eine nördliche sinistrale und eine südliche dextrale Scherzone. Die synsedimentäre Tektonik in den Budaer Bergen demonstriert den Deformationsstil innerhalb des abwandernden Blockes eng an der südlichen Grenzzone. Die tektonisch kontrollierte Sedimentation unterstreicht, dass die Ausquetschungstektonik bis in das späte Eozän hinein aktiv war.

\section{Abstract}

The Upper Eocene sequence of the Buda Hills consists of fluvial and shallow marine conglomerates, sandstones, bioclastic shallow-water limestone, marlstone and pelagic Globigerina marl. The succession illustrates rapid, overall subsidence of the area, from terrestrial environments to bathyal depths. Sedimentation occurred on slopes situated on the flanks of synsedimentary basement antiforms. Vertical growth of antiforms caused progressive tilting of beds, layerparallel extension by boudinage and faulting, and induced redeposition by mass flow. Antiforms are localised in the dextral Budaörs shear zone and in the Buda imbricate stack, which accommodated the dextral displacement. The latter is underlain by blind reverse faults probably merging into a detachment tault at shallow depths. These structures were formed by WNW-ESE oriented compression and NNE-SSW directed tension. The morphological expression of the imbricate stack is the SE-facing Buda slope.

The Bakony unit, while "escaping" from the Alps, was bordered by a northern sinistral and a southern dextral shear zone. Synsedimentary tectonics in the Buda

\footnotetext{
*) Authors' addresses: L. Fodor, A. MAGYARI, A. FoGARAsI, Department of Geology, Eötvös University, Múzeum krt. 4/A, H-1088 Budapest, Hungary, and M. KÁZMÉR, Department of Palaeontology, Eötvös University, Ludovika tér 2, H-1083 Budapest, Hungary Present address: L. FoDOR, Department of Applied and Engineering Geology, Eötvös University, Múzeum krt. 4/A, H-1088 Budapest, Hungary.
}

Manuscript received: 19. 1.91; accepted: 13. 7.1992 
Hills demonstrates the style of deformation inside the escaping block, close to the southern border zone. Tectonically controlled sedimentation suggests that escape tectonics was active as early as Late Eocene time.

\section{Résumé}

La séquence sédimentaire d'âge éocène supérieur des collines de Buda est constituée de conglomérats fluviatiles et marins, de grès, de calcaires bioclastiques et de marnes néritiques ou pélagiques à Globigerina. Cette succession correspond à une subsidence rapide, régionale, passant d'un environnement terrestre à un environnement bathial. La sédimentation s'est effectuée sur les pentes situées sur les flancs des anticlinaux synsédimentaires. Le soulèvement de ces anticlinaux a provoqué le basculement progressif des couches, une extension parallèle à la stratification avec boudinage et fractures, ainsi que le remaniement de sédiments par divers écoulements gravitaires. Les anticlinaux se situent dans la zone décrochante de Budaörs dont le déplacement dextre a été accompagné par un système d'écailles: la zone de Buda. Cette zone correspond à une pente complexe sédimentaire à vergence SE. Elle est caractérisée par des failles inverses aveugles qui se raccordent probablement à faible profondeur à une surface de décollement. Toutes ces structures ont été engendrées par une compression WNW-ESE et une extension NNE-SSW.

Durant l'échappement continental, l'unité de Bakony était bordée au nord par une zone cisaillante sénestre et au sud par une zone cisaillante dextre. La tectonique synsédimentaire dans les collines de Buda montre le style de la déformation à l'intérieur du bloc séparé, près de sa limite méridionale. La sédimentation, régie par la tectonique, indique que l'échappement continental avait déjà commencé à l'Eocène supérieur.

\section{Краткое содержание}

Верхнеэоценовая толща Будайских гор представлена абразионными конгломератами, песчаниками, биообломочными известняками, мергелями и пелагическими глобегериновьми мергелями. Эта последовательность осадков отображает быстрое всеобщее проседание района от верхнего уровня континента до батиальньх глубин. Накопление осадков происходило на древних склонах, расположенных на флангах синседиментационньг антиклиналей фундамента. Поднятие антиклиналей вызвало прогрессивное наклонение слоев, растяжение, отмечаемое будинажем и разломами, и переотложение вещества с потоками массы. Антиклинали простираются в правосторонней Будаершской зоне сдвигов Будайской чешуйчатой области, в которой накопился меланж. Будайская зона соответствует сложному склону, обращенному на юго-восток. Она подстилается скрытыми взбросами, вероятно припаянными к зоне срьга на небольшой глубине. Все эти структуры образовались при сжатии в простирании WNW-OSO и растяжении в направлении $\mathrm{NNO}-\mathrm{SSW}$.

Баконьские структурные элементы, выжимаемые из Алы, были ограничены левым сдвигом на севере и правым на юге. Синседиментационная тактоника в Будайских горах демонстрирует стиль деформации внутри выжимаемого блока, расположенного вблизи южной границы. Осадконакопление, контролируемое тектоникой, свидетельствует о том, что выжимание имело место уже в позднем эоцене.

\section{Introduction}

Continental escape is a common process in orogenic belts (TAPPONNIER, 1977; BURKE \& SENGÖR, 1986). Brittle deformation is often concentrated at the boundary of the escaping wedge, but faults formed in the same kinematic system cross-cut the internal part, too. Tectonically controlled sedimentation, if connected to the internal or border fault zones, may offer excellent temporal constraints to the motion history of the faults (e.g. HEMPTON \& DUNNE, 1984; TAPPONNIER et al., 1982; SENGÖR et al., 1985).

The Bakony Unit, the earliest recognized of the escaping wedges of the Alpine-Pannonian region (KovÁCS, 1983) was forced out between the Eastern and Southern Alps during Tertiary time. Detailed structural analysis and kinematic modelling describes the Neogene escape history and related fault pattern (RATSCHBACHER et al., 1989; CsONTOS et al., 1991). The idea of Paleogene motion is based mainly on displaced Permian-Oligocene facies boundaries and kinematic analysis (Fig. 1; KÁZMÉR, 1984; KÁZMÉR \& KOVÁCS, 1985; and BALLA, 1988a, FODOR et al., 1990a). In fact, kinematic models demonstrate that the Bakony Unit is only a part of the escaping North Pannonian block (Fig. 1b; BALLA, 1988a, b). It is generally accepted that during the Oligocene, dextral displacement was already going on along the southern border fault zone (Periadriatic and Mid-Hungarian 


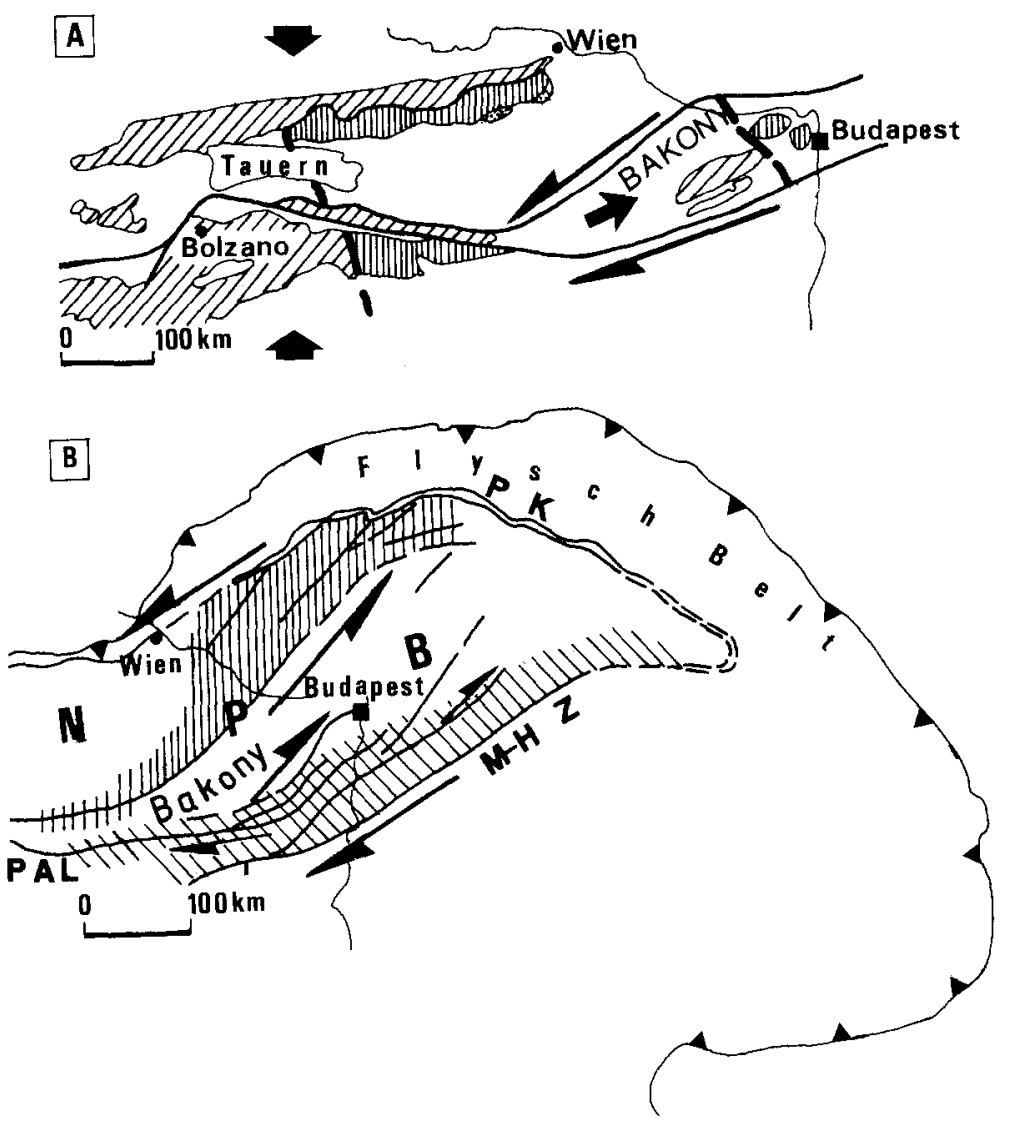

Fig. 1. Continental escape of the Bakony unit. (a) Triassic palaeogeography: the facies boundary (dashed line) between Main Dolomite (oblique haching) and Dachstein Limestone (vertical haching) is displaced to the east (after KÁzMÉR \& KovácS, 1985). (b) Kinematic analysis: the Bakony unit is part of the escaping North-Pannonian Block (NPB) which is bordered by sinistral and dextral strike-slip zones (vertical and oblique haching, respectively; after BALLA, 1988b). Tectonic units are shown in actual positions. PAL: Periadriatic Lineament; PK: Pieniny Klippen Belt; M-HZ: Mid-Hungarian Zone. Solid triangles indicate the external boundary of the Carpathian fold belt.

zone, BALLA, 1988a; RATSCHBACHER et al., 1989). The possibility of Eocene movement is generally neglected, or can only be suggested without relevant tectonic and/or sedimentological data.

After an extended period of erosion and bauxite deposition during the Early Paleogene, marine sedimentation started in the Middle to Late Eocene in the Bakony Unit (BÁLDI-BEKE, 1984; MINDSZENTY, 1984). Sediments were deposited in newly formed, separate basins. Abrupt facies changes in depressions, occurrence of gravity-displaced deposits, rapid subsidence and a rhombohedral outline of the sedimentation area led BÁLDI \& BÁLDI-BEKE (1985) to suggest a strikeslip-related origin for the basin system. The assumed right-lateral shear zone was attributed to continental escape (ROYDEN \& BÁLDI, 1988). Nevertheless, neither original paleogeography, nor Eocene fault patterns have been described, therefore, even the right-lateral sense remains doubtful. In fact, these features can hardly be recognized, since the basins have been partly eroded, partly covered by younger sediments and were deformed by subsequent tectonics.

In the present study we discuss the sedimentology and tectonics of the eastern part of the Transdanubian Central Range (referred to as Bakony, after the largest topographic unit), the Buda Hills. Here original Late Eocene palaeogeography and structures can be recognized and separated from the effects of younger tectonic events. We describe the kinematic and dynamic character of tectonic structures and their effect on sedimentation and provide evidences for Late Eocene escape movement of the Bakony Unit.

\section{Geological settings}

Part of Buda Hills is made of Middle to Upper Triassic dolomites and limestones. These rocks were slightly deformed during the Cretaceous, the main structure of this phase being a NW-SE trending syncline 


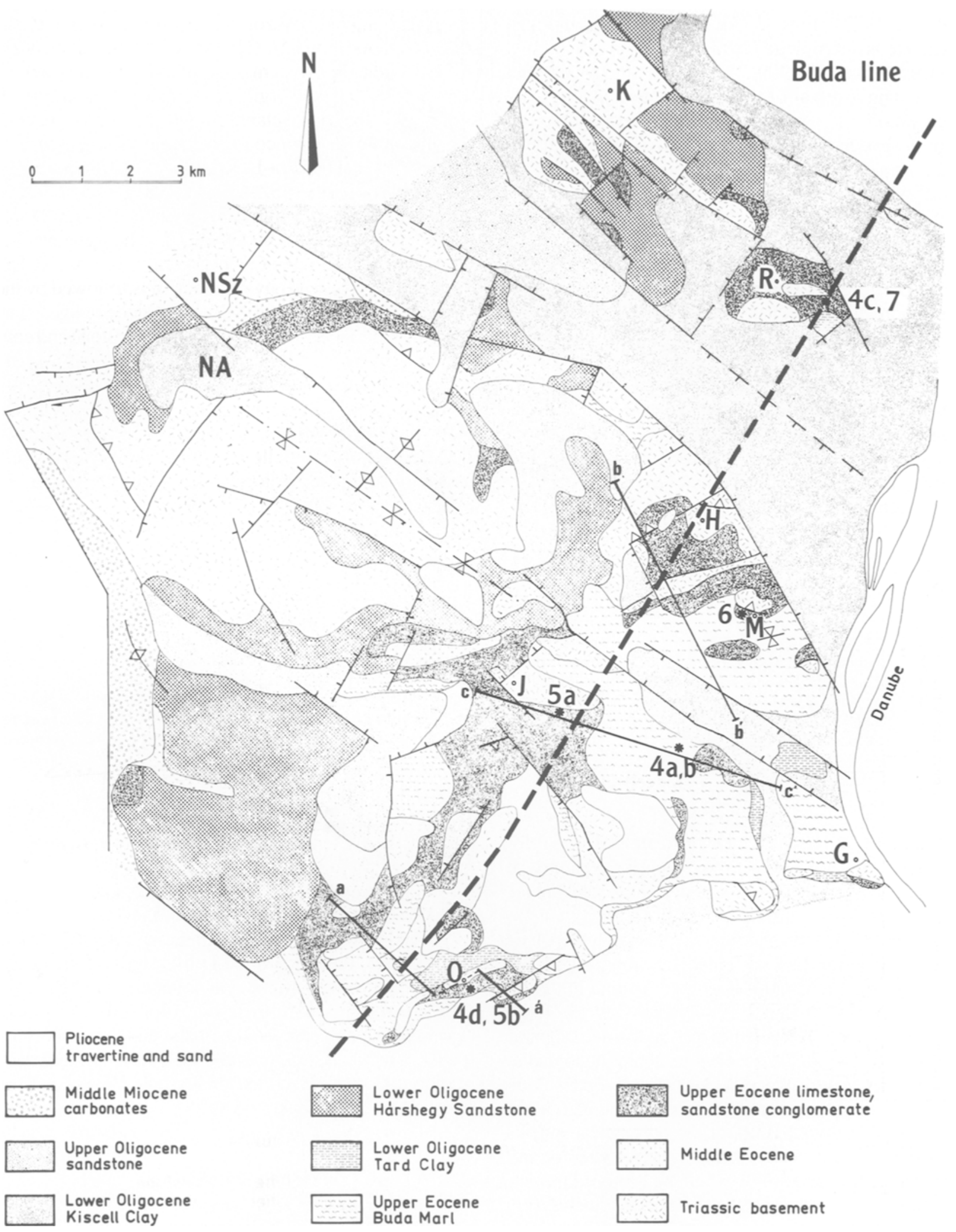

Fig. 2. Geological map of the Buda Hills (after WEIN, 1977, simplified). Location is in the black quadrangle of Budapest on Fig. 1. Stars and numbers correspond to figures, $a-a^{\prime}, b-b^{\prime}$ and $c-c^{\prime}$ are sections in Figs. 11 and 12, respectively. Hills: R. Róka, K.: Kevély, NSZ: Nagy-Szénás, H.: Hármashatár, J.: János, O.: Odvas, M.: Mátyás, G,: Gellért Hill. NA.: Nagykovácsi Basin. 
(WEIN, 1977) (Figs. 2, 3). This Triassic basement syncline is cut by Late Cretaceous lamprophyre dykes (Kubovics et al., 1989).

A long interval of erosion was terminated by the deposition of (Cretaceous?)-Palaeogene bauxites, Middle Eocene coal measures and overlying limestonemarl sequence (SzÖTS, 1956), occurring mainly in the northwestern Nagykovácsi depression. The Late Eocene sequence starts with sandstones, conglomerates and breccias of alluvial and shallow marine origin (Fig. 3). Clasts were derived from local basement rocks, or have been transported as much as $30 \mathrm{~km}$ by rivers or longshore currents (HORVÁTH \& TARI, 1987).

This series is overlain by shallow marine limestones containing red algae, large foraminifers (Nummulites, Discocyclina), echinoid fragments, molluscs and corals (MONOSTORI, 1965). These represent variable shallow water carbonate environments associated with moderate subsidence (KÁZMÉR, 1985). The limestone gradually passes into a bioclastic calcareous marl, the "bryozoan marl". Its fossil content: echinoids, molluscs and particularly, bryozoans suggest deep neritic depositional environment (KÁZMÉR, 1985; SZTRÁKOS, 1987). The bryozoan marl is followed by thin-bedded marl and laminated argillaceous marl (Buda Marl). It contains abundant planktonic foraminifers, nannoplankton and ostracods of Late Eocene-earliest Oligocene age (BÁLDI-BEKE, 1972; BÁLDI et al., 1984; MONOSTORI, 1987; SZTRÁKOS, 1987). These fossils suggest a bathyal origin for the sediments (BODA \& MONOSTORI, 1972; BÁLDI, 1986). The Buda Marl is overlain by the Lower Oligocene laminated Tard Clay, formed in an anoxic environment. It is followed by the pelagic Kiscell Clay of Middle Oligocene age. The shallow marine quartzose Hárshegy Sandstone and conglomerate is synchronous with the uppermost Tard Clay and the lower Kiscell Clay (BÁLDI, 1986). The Lower Oligocene sequence is capped by neritic Upper Oligocene sandstones, followed by Early Miocene coarse clastics, Middle Miocene carbonates, Upper Miocene sandstone, Pliocene fresh-water limestone and Quaternary deposits (WEIN, 1977).

(a)
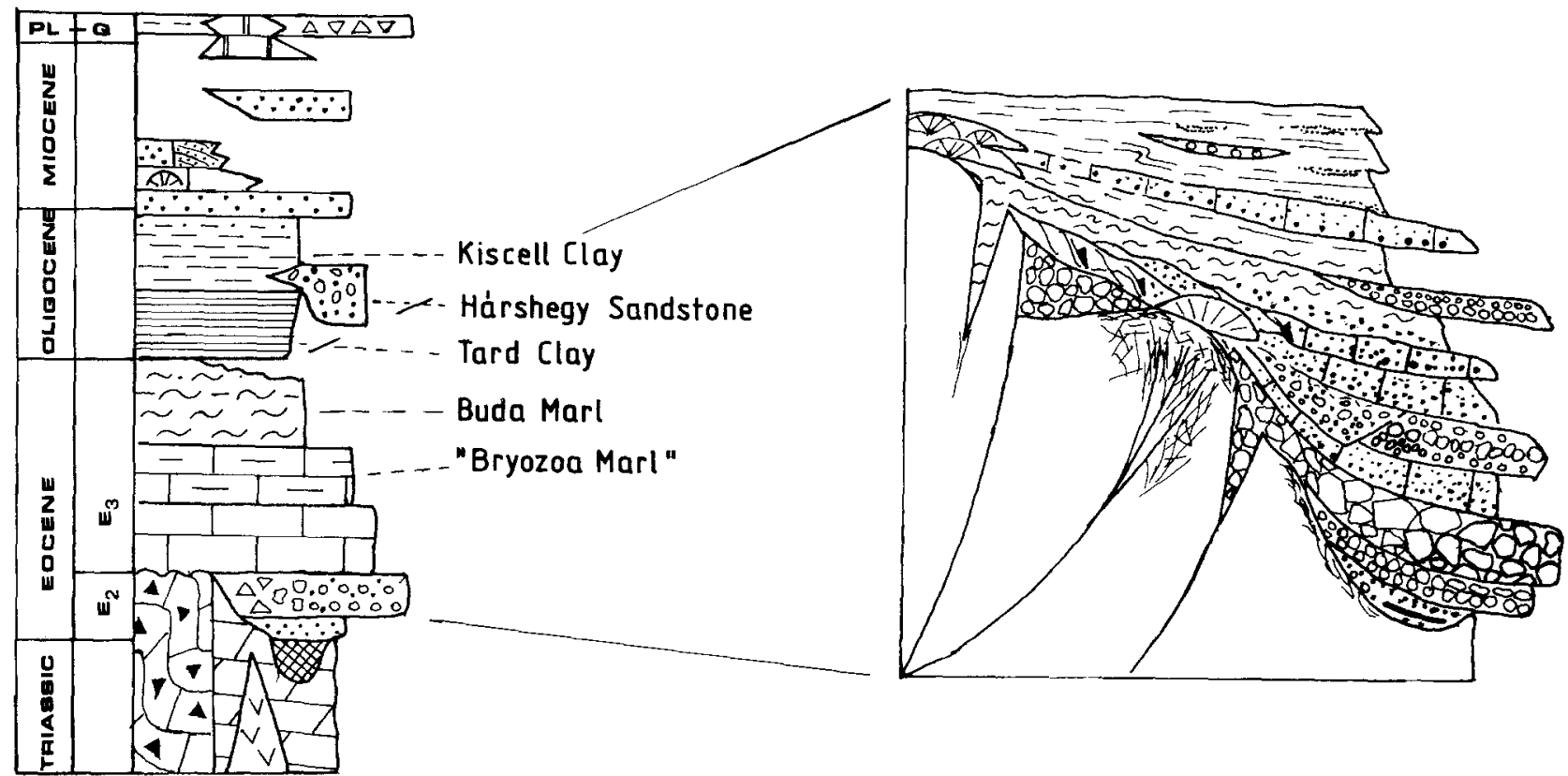

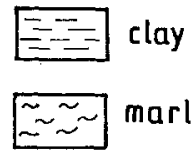

ITA shallow water limestone with reefs

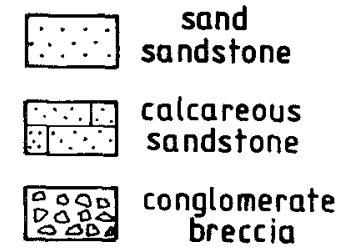

Fig. 3. Stratigraphic column of the Buda Hills. (a) after Wein (1977) and BÁLDI (1986), (b) detailed column of the Upper Eocene sequence. 

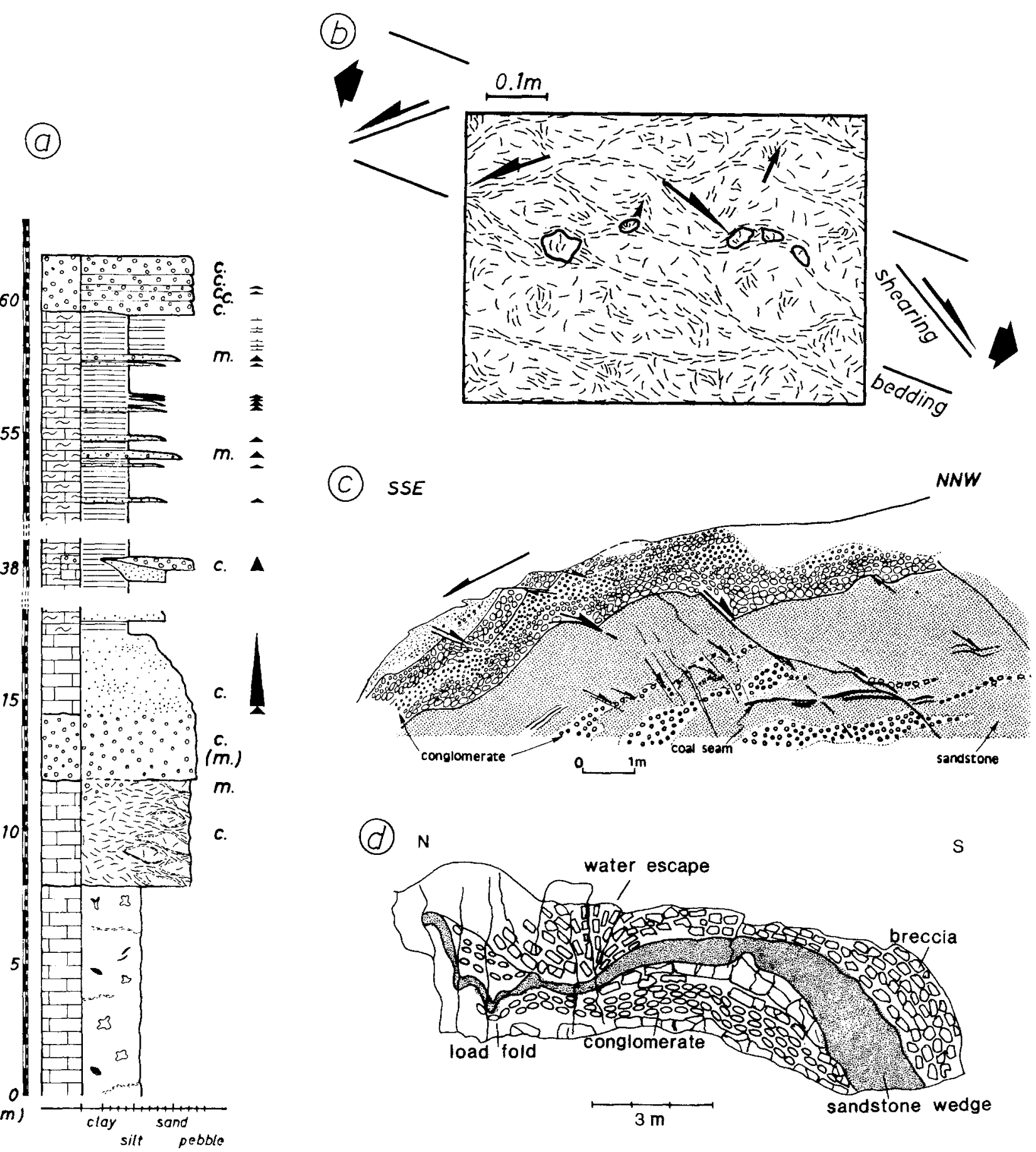

(d) $\mathrm{N}$

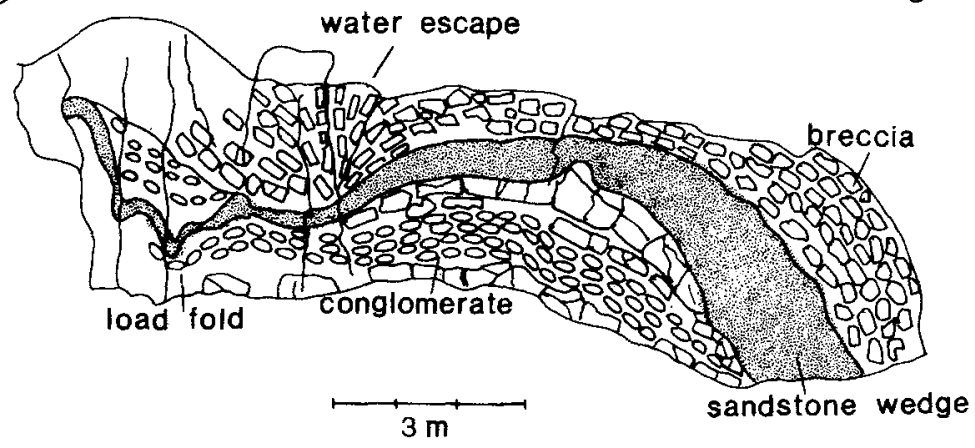

Fig. 4. Redeposition and soft-sediment deformation in the Upper Eocene sequence. (a) Redeposited conglomerates and calcareous turbidites on the Martinovics Hill (FOGARASI, 1991). m: matrix-supported, c: clast-supported. (b) Parallel alignment of Discocyclina tests due to soft-state shearing and boudinage in semi-lithified lime mud (Martinovics Hill). Arrows indicate the initial stage of the necking of boudins. (c) Soft-sediment deformation in conglomerate and calcareous sandstone (Róka Hill). Note that faults are dying out below the top of the thick conglomerate layer. Faults in the conglomerate are truncated. Thin coal seams embedded in the sandstone were disrupted during redeposition or soft-sediment deformation. (d) Synsedimentary slump fold on the Odvas Hill (after MAGYARI, 1991b). 
Early Oligocene palaeogeography is characterized by two different regions separated by the NNE-SSW trending "Buda Line", marked in the field as a zone of intense silicification of the Hárshegy Sandstone (BÁLDI $\&$ NAGYMAROSI, 1976). West of the Buda Line, earliest Oligocene erosion was followed by shallow marine deposition of the pure quartzite Hárshegy Sandstone. To the east of the line, the laminated, pelagic Tard Clay, then the similarly pelagic Kiscell Clay accumulated in a rapidly subsiding basin. Recognizing the lack of interfingering formations BÁLDI (1982) suggested that the sharp facies boundary corresponds to a single strikeslip fault. BALLA \& DUDKO (1989, p. 25), while accepting the existence of this facies boundary, emphasized that a tectonic line of this trend cannot be observed on the surface.

The westward termination of the pelagic Buda Marl during Late Eocene lies at the Buda Line; therefore, the palaeogeographic pattern recognized for Oligocene sediments was probably established as early as the Late Eocene. Describing Late Eocene facies pattern and tectonics, we intend to determine the nature of "Buda Line", the most important facies boundary in the Buda Hills.

\section{Sedimentary features}

\section{Resedimentation}

Most beds were deposited by a variety of sediment gravity flows. Conglomerates at the bottom of the Upper Eocene sequence are usually massive, and rarely poorly bedded; pebble orientation is usually random, rarely subhorizontal, or weekly imbricated. Some layers show inverse-to-normal grading. All features suggest deposition by high viscosity debris flows. Conglomerate and sandstone strata embedded in the Buda Marl are poorly to well-stratified, well-sorted, and rarely show weak normal grading; probably these were deposited by grain flows (Fig. 4a). Limestone shows distinct soft sediment deformation caused by slow downslope creep (Fig. 4b) (FogARASI, 1991). The Buda Marl contains alternating turbidites with $\mathrm{A}-\mathrm{B}-(\mathrm{C})$ and $(\mathrm{C})-\mathrm{D}-\mathrm{E}$ divisions of the Bouma sequence. Beds consist of bioclasts derived from shallow-water carbonate depositional environments (BODA \& MONOSTORI, 1972; VARGA, 1985; BÁLDI, 1986).

This short description shows that high viscosity flows were deposited in the lower part of the series, while less viscous flows containing more water and disintegrated grains characterize the upper part. This evolution reflects growing transport distance of gravity flows in a gradually subsiding and enlarging basin.

\section{Soft-sediment deformation}

Deformation phenomena affecting unconsolidated, or semi-consolidated sediments are here termed "softsediment deformation". The unlithified state of sediments is suggested by: (1) plastic extension and thinning of layers; (2) internal reorientation of grains due to loading and plastic shearing.

Features produced by layer-parallel extension are similar in appearance to tectonic boudinage: one of the layers thins and pinches out while the overlying and underlying ones preserve their thickness and continuity. Sometimes the lenses formed in this way are connected to each other by narrow necks. If the displacement was large enough, the high-viscosity layer disintegrated into boudin-like lenses or angular clasts. The latter resembles the features described by WALDRON et al. (1988) as "chocolate tablet" boudins formed by extension fractured boudinage (FOGARASI, 1991). Lenses consist of massive bioclastic limestone, while the matrix is clayey limestone. There is no distinct surface, but a thin $(0.1-1 \mathrm{~cm})$ transition zone between the lenses and their matrix, suggesting a rather limited mixing of highly cöhesive masses.

Around the lenses and thin sandy intercalations of conglomerate, closely spaced anastomosing planes occur parallel to bedding, or slightly oblique to it. Foraminifers are oriented parallel to these planes, in contrast to massive lenses, where forams are not oriented and more abundant (Fig. 4b). Fossils were probably rotated parallel with each other during the deformation of the soft sediment.

The geometry of anastomosing planes resembles extensional crenulation cleavage fractures (PLATT \& VISSERS, 1980). In spite of the different physical circumstances, we interpret this structure as a result of shearing of highly viscous, almost lithified sediments. Lenses contoured by these shear planes represent shear boudins (WALDRON et al., 1988). Both type of boudins are products of progressive bed attenuation and reflect layer-parallel extension due to slow downslope creeping of the highly viscous material.

In some outcrops we observed small-scale faults, which are clearly restricted to one single layer. Other structures can hardly be called faults, since there are no distinct surfaces but only a thin, plastically deformed zone (Fig. 4c). Both features formed by synsedimentary or soft-sediment deformation, probably related to redeposition of the sediment.

Close to steep erosional surfaces layers are deformed to a steeply inclined position. Soft-sediment deformation frequently occurs in the buckled segments of layers, indicating that bending partly took place before lithification. 
Slump folds have been described in sediments of different grain size, ranging from marls to coarse breccias (FODOR \& KÁZMÉR, 1989). At Odvas Hill one particular fold occurs in a sandstone layer sandwiched between a lower conglomerate and an upper breccia bed (Fig. 4d). The lamination of the pebbly, silty sandstone shows deposition by traction currents. Both thickness and dip of laminae gradually increase downslope and from top to bottom, respectively. Curvature of the fold in the lower conglomerate is larger than in the upper breccia. We suggest that the deposition of the sandy wedge and gradual steepening of the laminae were contemporaneous with the growth of the fold below.

In the upper part of the conglomerate the otherwise randomly oriented pebbles have been stated parallel to bedding (Fig. 4d). Both this plane and the sandstone layer undulate. The formation of this "pebble train" and the undulation took place in cohesive sediment due to uneven loading of the overlying bed (SURLYK, 1989, pers. comm.). "The loading of the overlying breccia could induce the escape of water, indicated by the subvertically oriented clasts (Fig. 4d). In other localities pebble trains form asymmetrical rarely overturned folds; there, the sediment was not only loaded, but dragged by the slowly creeping overlying layer. We suggest the name "pebble fold", or "load fold" for these features.

\section{Tectono-sedimentary observations}

\section{Rockfall}

Near János Hill, a single layer of subrounded Triassic dolomite boulders, up to $2 \mathrm{~m}$ in diameter are embedded in fluviatile sandstone/siltstone (Fig. 5a). The scene might have been similar to the rockfall photographed by MARTINIS (1977) after the Friuli earthquake in Italy: large boulders fallen from adjoining hillsides are scattered in the alluvial plain of the Tagliamento river.

At Odvas Hill, a $5 \mathrm{~m}$ thick, massive, clast-supported breccia layer covers Eocene conglomerate beds. The closely spaced angular clasts were only slightly displaced from each other; obviously, an originally fractured rock body slid into the sea, while its components suffered only minor rearrangement. The fall of these bodies was probably initiated by seismic shocks, which fractured elevated basement rocks (TARI, 1989, pers. comm.; MAGYARI, 1991b).

\section{Decrease in dip}

One of the most striking features of the sediments is the remarkable range of dips from 5 to $65^{\circ}$. Part of this variation must be synsedimentary because the dip of Eocene strata is often steeper than the dip of the underlying Triassic basement. As a general rule the dip decreases from the bottom to the top of the sequence. Upward decrease is clearly visible in the field: in a small fan on Odvas Hill the dip gradually decreases from $45^{\circ}$ to $15^{\circ}$ (Fig. 5b), while on Út Hill limestone beds dipping at $45^{\circ}$ have been eroded and covered by marl dipping at $20^{\circ}$ (BÁldD et al., 1983; FODOR \& KÁZMÉr, 1989). Each case indicates continuous, or episodic tilting of strata during sedimentation. In other cases tilting (deformation) of beds seems to be partly post-sedimentary.
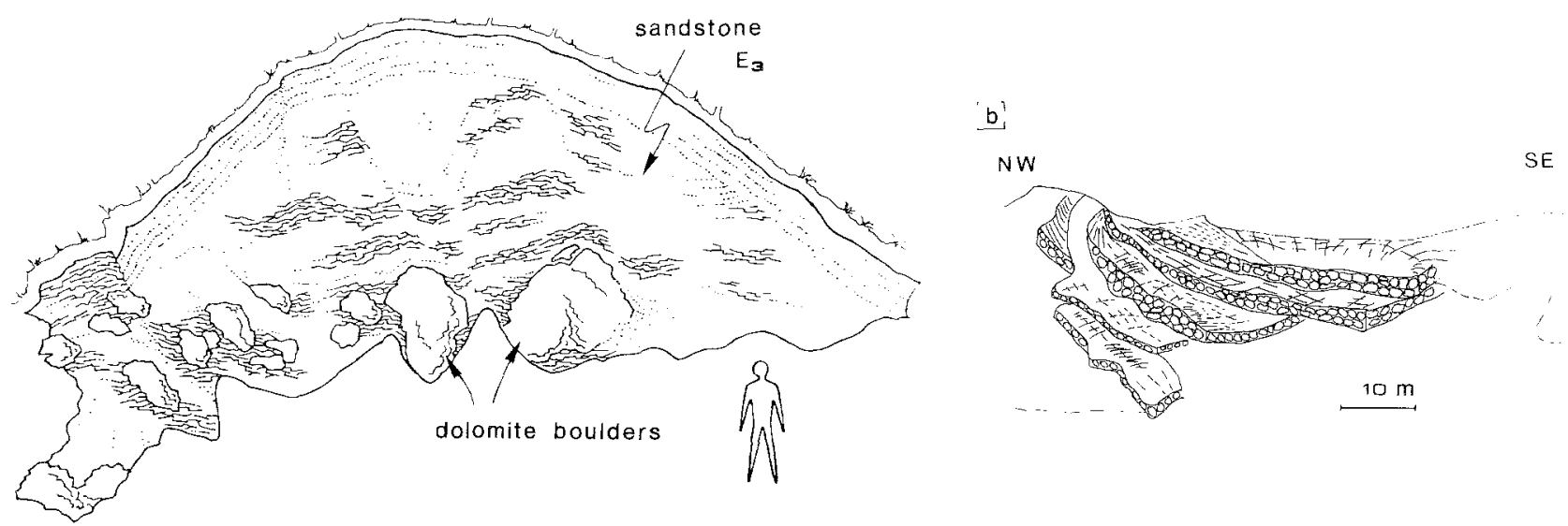

Fig. 5. (a) Earthquake-induced (?) fall of dolomite blocks into sandy silt near the János Hill (drawn by G. TARI). (b) Schematic crosssection of a small conglomerate fan at the Odvas Hill. Gradually decreasing dip suggests synsedimentary tilting of layers. For location see Fig. 2 (after MAGYARI, 199 lb). 


\section{Fault-bounded talus cones}

At Mátyás hill a small, semicircular breccia-conglomerate talus cone is bordered by a fault (Fig. 6). Its diameter is less than 120 metres; nearer to the fault the basement is directly overlain by bioclastic limestone (JASKÓ, 1948). The conglomerate body bears no internal structure, but contains thin sand/silt intercalations, one of them capping the cone. These acted as slide planes, as shown by a slump body overlying the sandstone. Bioclastic limestone displaying a conspicuous sheared appearance, with boudins, overlie both the cone and the Triassic basement. These observations indicate that the boundary fault grew contemporaneously with sedimentation. The bulk of the displacement took place prior to the deposition of the limestone. The fault is nearly vertical and shows apparent reverse displacement. The dip of the overlying limestone is rather excessive and can hardly be original, so we suggest that the whole block (containing the fault) has been tilted. Restoring the possible tilt $\left(20-30^{\circ}\right)$, the fault apparently displays normal displacement. However, the steep dip and some microfaults in the surrounding Eocene limestone suggest that it may also have a dextral strike-slip component.

\section{Neptunian dykes}

Many Late Eocene sedimentary dykes cut the underlying rocks. These are 1 to $120 \mathrm{~cm}$ wide, tens of metres long and are filled by breccia, conglomerate, sandstone, or marl; many of the infillings were later silicified. Sediments not only filled some dykes, but were injected into the fissures of the host rock by overpressured fluid. The injection might have been induced by the tectonic movement itself which opened the dykes (e.g. BORDET et al., 1982). Dykes are mostly oriented WNW-ESE (MAGYARI, 1991a). They represent tension gashes and permit the reconstruction of the stress field.

$$
\text { Palaeomorphology }
$$

Stepped erosional surfaces are found below the upper Eocene sequence; a fine example was found on the Róka Hill (for location see Fig. 2). One can differentiate a nearly horizontal upper "plateau" and a lower steep slope (Fig. 7). Eocene sediments are generally eroded from the plateau and, if they are present, their thickness is reduced; the sediments do not show redeposition and soft sediment deformation. Basal clastic layers are often missing; coral patch reefs and algal mounds are directly located on the basement. A relatively elevated

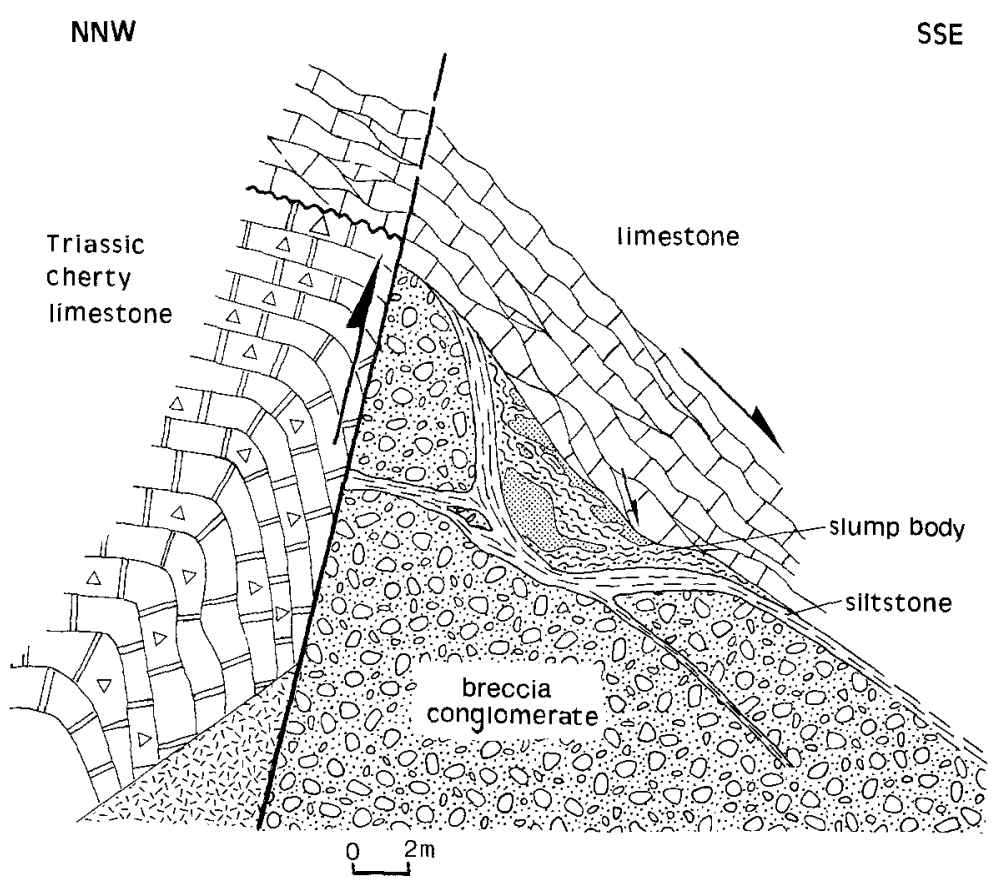

Fig. 6. Cross-section of a fault-bounded breccia talus cone on the Mátyás Hill. The breccia-conglomerate cone is separated by sheared siltstone. The overlying limestone bears features of boudinage and shearing in a semi-lithified state. 


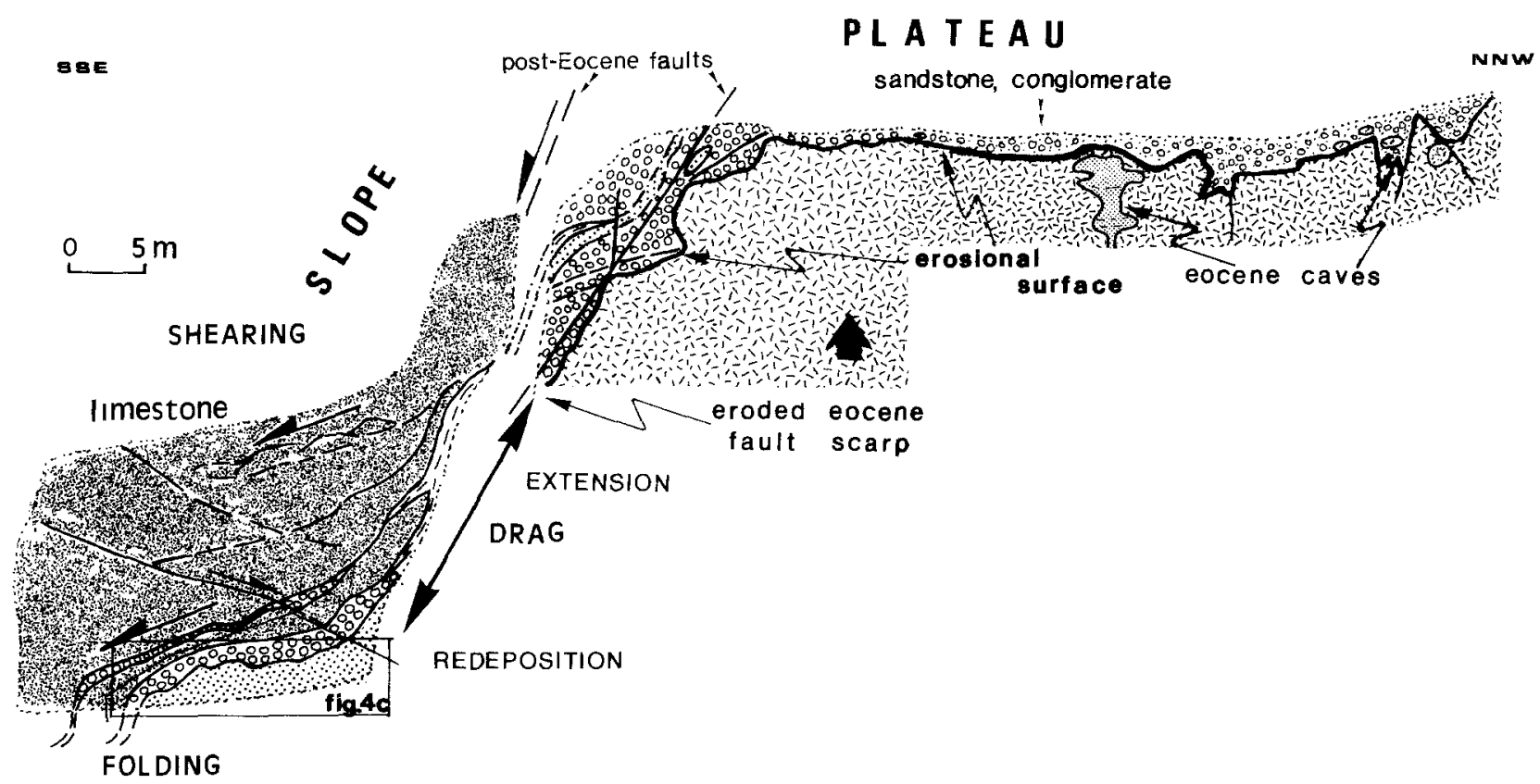

Fig. 7. Late Eocene palaeoslope on the Róka Hill. Note that faults controlling the slope propagated through sediments after Eocene time.

position of the plateaux is indicated by pre- and synsedimentary karstification and unconformities (Fig. 7) (NÁDOR, 1992).

Considerably thicker sequences occur on the steep part of the erosion surfaces. On the Róka Hill, most of the layers pinch out toward the steeply-dipping erosion surface. The lower sandstone and conglomerate layers were tilted and deformed into a steep attitude. The dip of the overlying limestone is less significant, indicating the synsedimentary character of the tilting. All observations suggest that the topographic difference between the plateaux and slopes increased gradually. The soft sediment was often redeposited by different types of gravity mass flows. Redeposition was associated with soft sediment deformation during downslope movement (Figs. 4c, 7).

The steep, eroded surfaces represent the upper part of a fault scarp or a folded-tilted part of an originally more gentle slope. Some of the steep palaeoslopes may have formed prior to sedimentation, but their activity during deposition is beyond doubt.

Post-Eocene faults often occur along the slopes, either by propagation of buried Eocene faults, or by fracturing along pre-existing discontinuities, for example, basement-cover contacts, or steeply dipping layers (Fig. 7).

\section{Tectonic observations}

Microtectonic measurements reveal the existence of two main stress fields which affected the area during the
Tertiary (BERGERAT, unpublished data; BERGERAT et al., 1984; and own measurements). The younger one corresponds to ESE-WNW to SE-NW extension, the maximum stress axis being vertical or horizontal (Fig. 8). In this stress field, inherited fractures trending from NNW-SSE to ENE-WSW were reactivated as normal or normal-oblique faults (Fig. 8b). NW-SE to N-S trending dextral, and ENE-WSW oriented sinistral strike-slip faults were associated with normal faults (Fig. 8a). Reverse faults or folds occurred locally, e.g. at the edge of Gellért Hill (BALLA \& DUDKO, 1991). Synsedimentary tension joints and faults observed on Tétény Plateau, at the southern vicinity of the Buda Hills prove that the deformation is of Middle Miocene age (Fig. 8c) (BERGERAT et al., 1983; PALOTÁs, 1991). Faulting affected lithified Middle Miocene limestone and shows the persistence of tectonic activity during Late Miocene and Pliocene times.

The older stress field was represented by WNWESE to NW-SE compression, and NNE-SSW to NESW extension. Dextral, and sinistral strike-slip and normal faults trend E-W, NNW-SSE and NW-SE, respectively (Fig. 9). NNE-SSW to ENE-WSW trending elevated areas can be considered as compressional ridges. Parallel reverse faults and folds are rarely shown on geological maps (e.g. WEIN, 1977), or described by earlier authors (citations in BALLA \& DUDKO, 1991).

Microfaults affect Triassic, lithified Eocene, and Lower Oligocene rocks (Hárshegy Sandstone and Tard Clay). While the latter rocks were deformed during the 
Late Oligocene-Early Miocene, microfaults in the Triassic and Eocene may have an Early Oligocene, or even Eocene age. Synsedimentary structures demonstrate the persistence of this stress field during Late Palaeogene. First, we refer to Late Eocene neptunian dykes, which are parallel to the direction of compression (Fig. 10) and can be considered as tension fractures ("tension gashes") formed in this stress field
(MAGYARI, 1991a, b). Similarly oriented sedimentary dykes are filled with Hárshegy Sandstone (middle Lower Oligocene) in the southern part of the Buda Hills. WNW-ESE oriented chalcedony dykes (tension gashes) fill the Hárshegy Sandstone (Fig. 9) (BÁLDI \& NAGYMAROSI, 1976). These dykes are associated with silicifying hydrothermal solutions which did not affect Middle Oligocene Kiscell Clay. Their age is latest Early
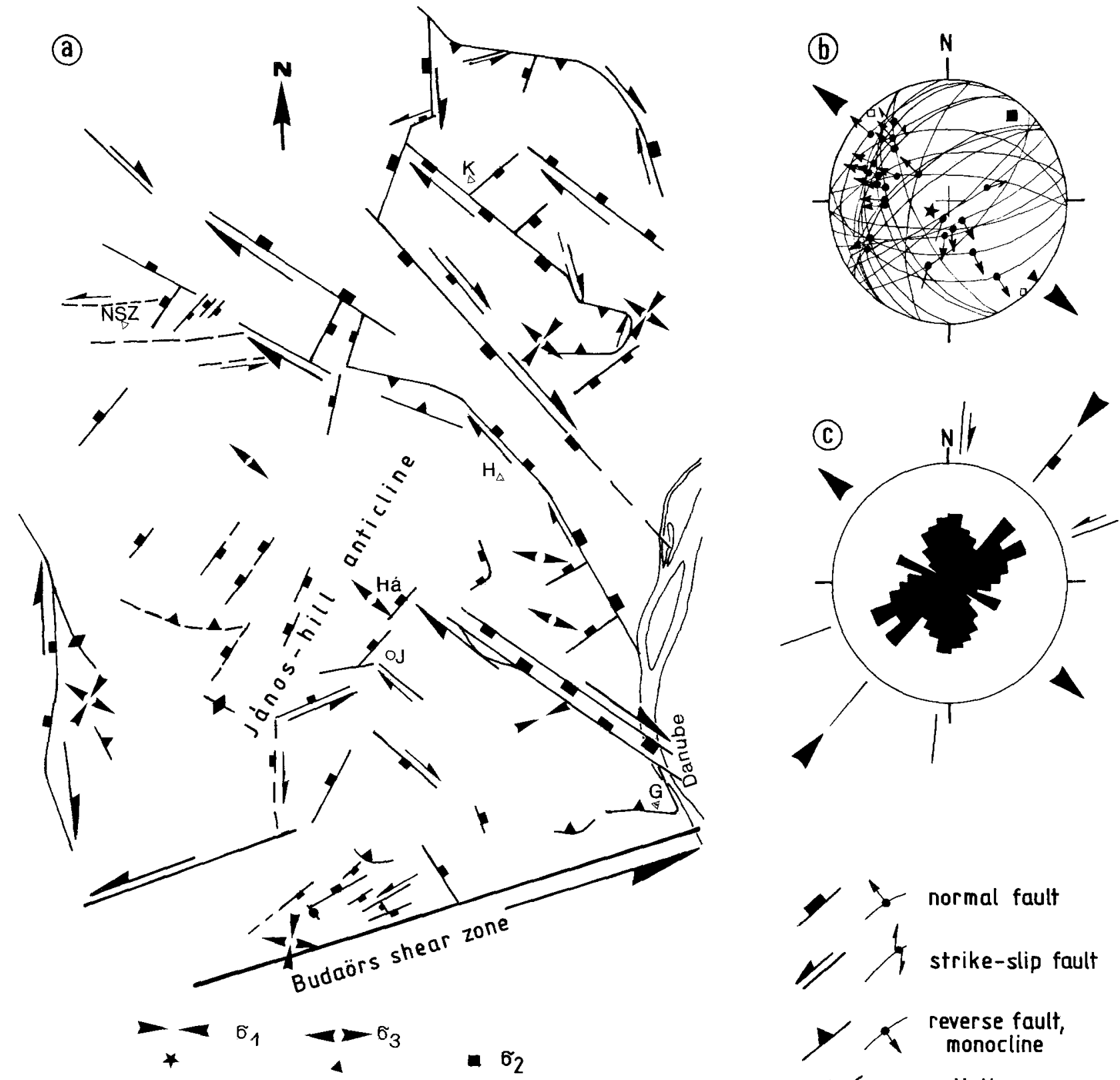

Fig. 8. (a) Stress field and structural pattern of the Buda Hills during Middle Miocene-Pliocene (own data, BERGERAT et al., 1984, and Bergerat, pers. comm). (b) Stereonet showing normal or normal-oblique faults, reactivating earlier discontinuities on the Hárs Hill (Há). (c) Rose diagram of synsedimentary, Middle Miocene faults on the Tétény Plateau (PALOTÁs, 1991). Except for normal separation, dextral and sinistral displacement were also confirmed along some faults. $\sigma 1, \sigma 2$ and $\sigma 3$ are maximal, medium, and minimal stress axes, respectively, obtained by numerical analysis of microfault data using the method of ANGELIER (1984). Stereographic projections are in Schmidt net, lower hemisphere. for topography see Fig. 2. 
Oligocene. The parallel nature of Late Eocene and Early Oligocene dykes and the direction of compression shows that the stress field did not change considerably after Middle Eocene and before Middle Miocene times and that tectonic movements were more or less continuous during this time span.

\section{Synsedimentary or post-sedimentary structures}

Because of the persistency of the stress field, Late Eocene and Oligocene-Early Miocene structures cannot be separated by structural methods only. However, combined sedimentological and tectonic observations permitted us to separate Oligocene and Late Eocene structures (Fig. 9, 10).

First we analyzed the faults figured on earlier maps. The kinematics of these structures was determined on the basis of the direction of main stress axis and the relative displacement of the rocks. After that we examined Eocene sediments occurring near a post-Eocene structure and looked for the erosional surfaces between the Triassic and Eocene rocks. In most of the cases Late Eocene palaeo-slopes were found at locations, where earlier maps only indicate post-Eocene (Oligocene) faults. Synsedimentary structures in Eocene or in base-

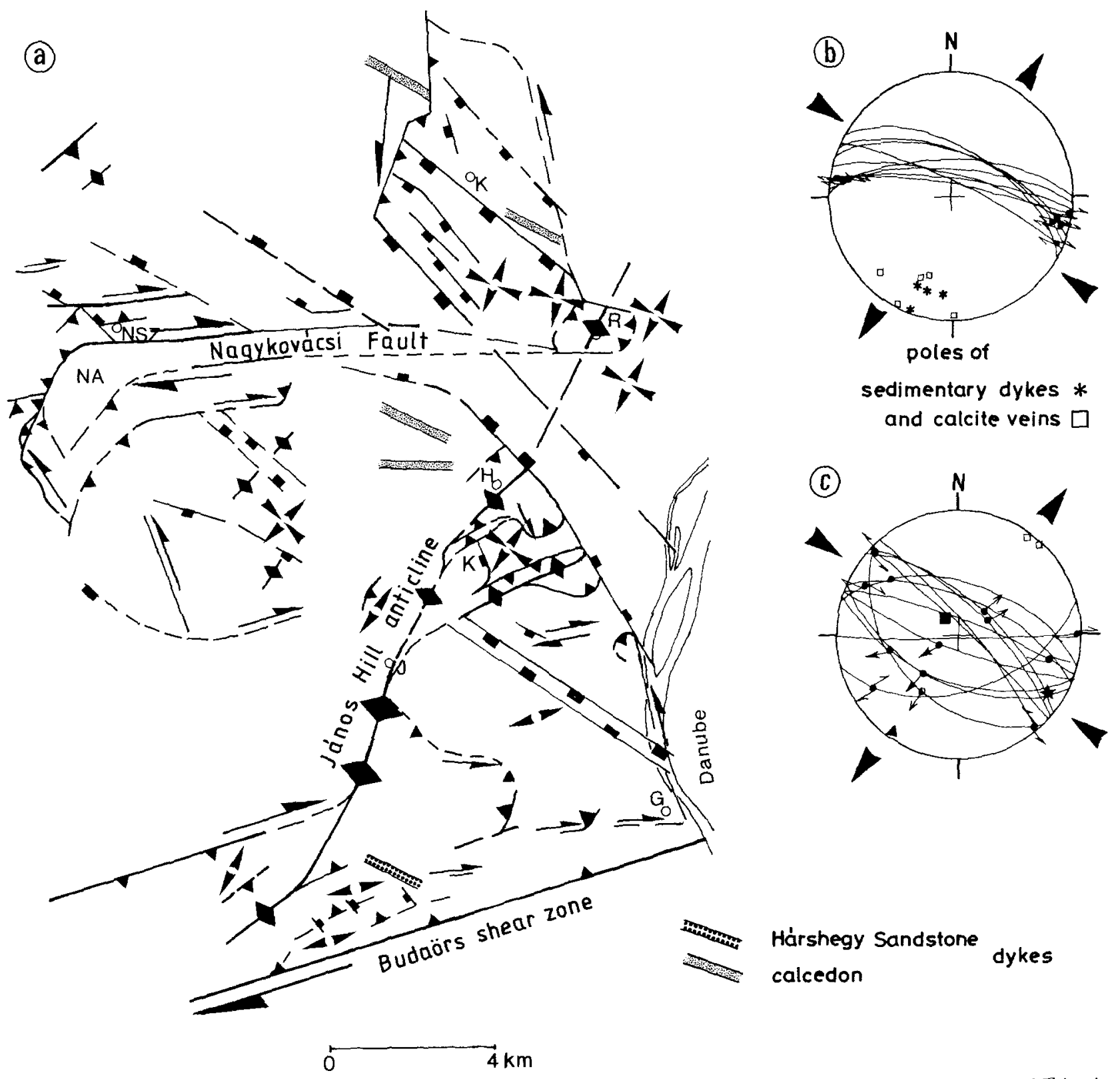

Fig. 9. (a) Stress field and structural pattern during the Oligocene-Early Miocene. (b) Dextral faults between Eocene and Triassic rocks $1 \mathrm{~km}$ to the west along strike from the Róka Hill paleoslope. (c) Microfault pattern near the Kecske Hill (Ke). For explanations of symbols see Fig. 8 . 
ment rocks can be either visible or remain hidden (Fig. 6 versus Figs. 5b, 7).

Our tectonical-sedimentological analysis suggests, that most faults produced by the Eocene-Early Miocene phase were already active in the Late Eocene. Some of the faults turned out to be clearly Late Eocene and not to be active in Oligocene, in contrast to the interpretation of earlier maps (Fig. 6). Other structures controlling the slopes were reactivated after the sedimentation, during the Oligocene-Early Miocene or even later (Figs. 7-9).

\section{Description of Eocene structures}

The Triassic basement rocks in the Buda Hills form numerous long ridges. The orientation of these paleoridges (WSW-ENE to SSW-NNE) are almost perpendicular to the orientation of compression (WNW-ESE to NW-SE), so they represent true antiforms. Sedimentological analysis prove that most of these antiforms were bordered by slopes during Late Eocene time (Fig. 10).

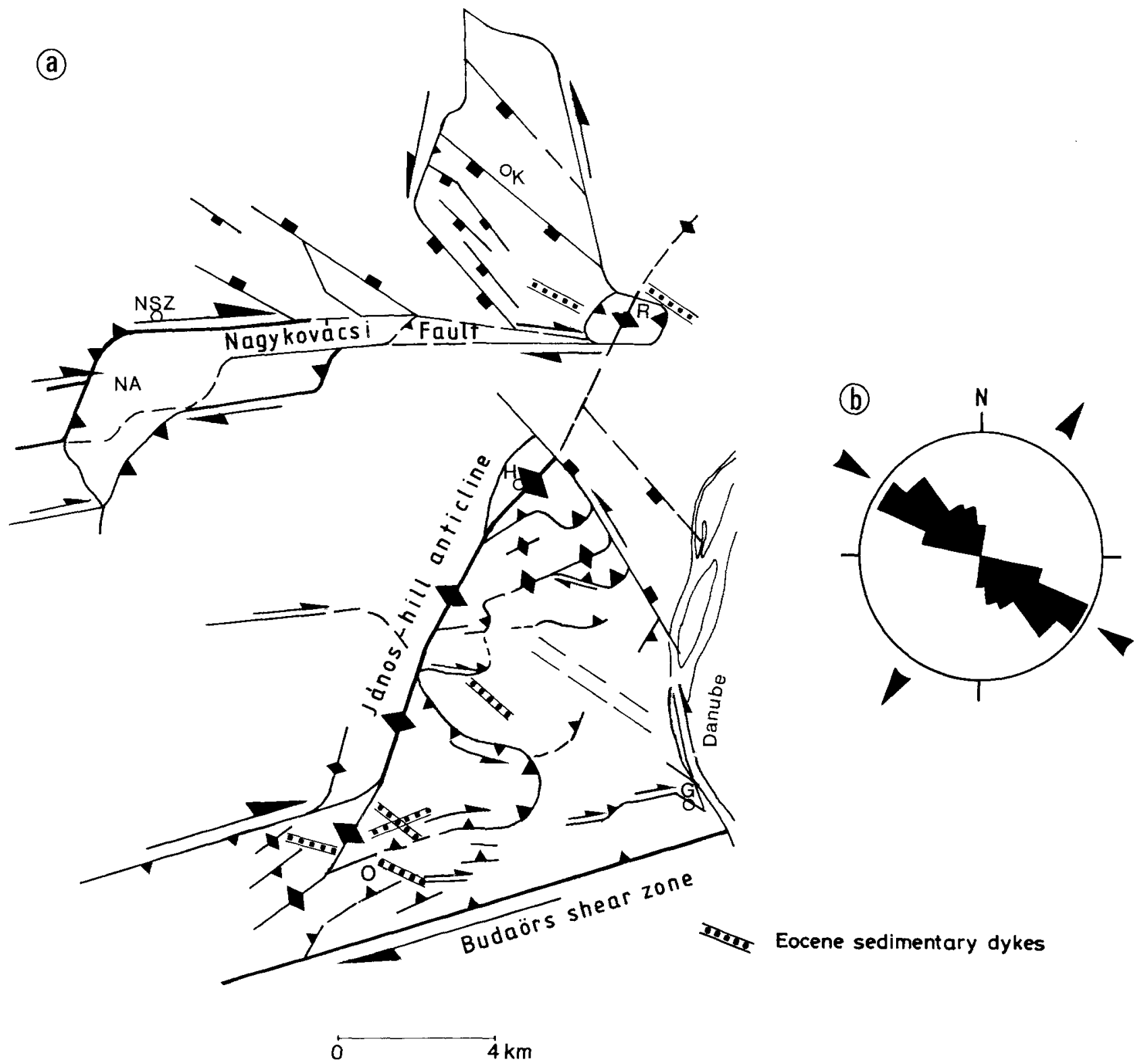

Fig. 10. (a) Stress field and structural pattern during the Late Eocene. (b) Rose diagram shows the strike of 100 synsedimentary dykes measured in the southern Buda Hills (O) by MAGYARI (1991b). For explanations of symbols see Fig. 8. 
(a)

SE

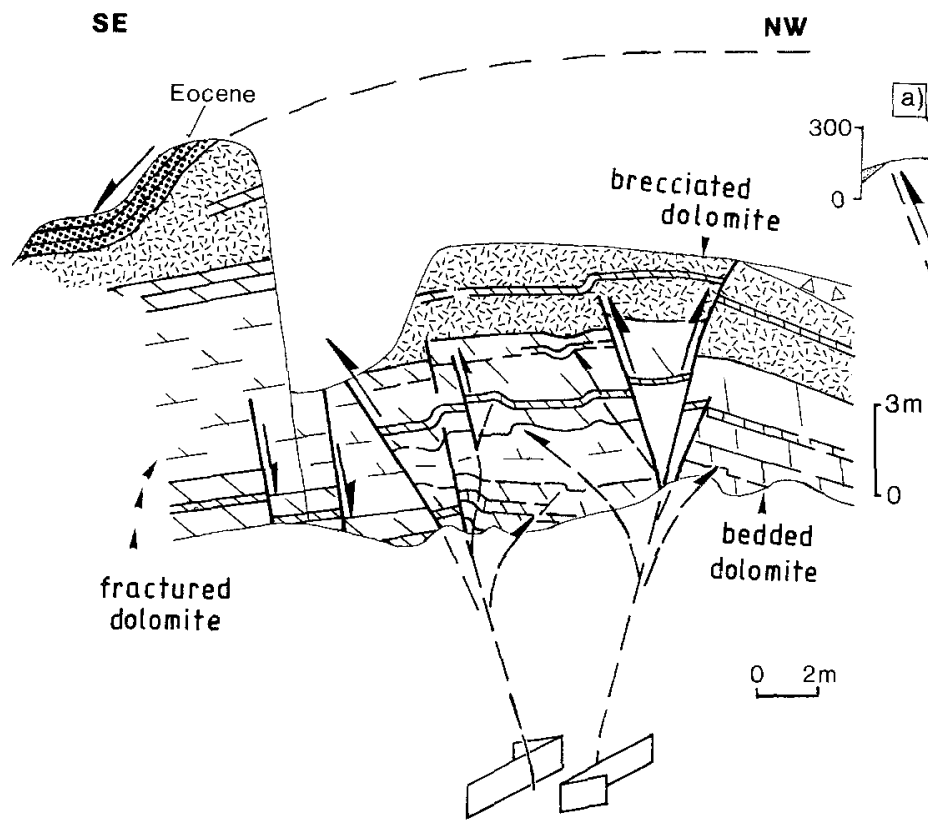

(b)
NW
SE

\section{.}


surface. It is probable that the reverse faults continue below the antiforms and monoclines, but did not propagate up to the actual surface or reach the Late Eocene sea bottom (Figs. 12b). These Eocene ridges represent fault-propagation anticlines (SUPPE, 1983) in front of a blind reverse fault tip.

The highest antiform extending from Budaörs in the south to Róka Hill in the north is more or less continuous, while others are laterally restricted (Fig. 10). The latter ones are connected by lateral ramps (BUTLER, 1982), e.g. at Mátyás Hill. The smaller anticlines and monoclines gradually decrease in height and are slightly asymmetric to the SE. These form a SE-vergent imbricate stack, called here the Buda imbricate zone. It may represent the accommodation zone for the dextral dis placement along the Budaörs shear zone.

Uniform vergency suggests that anticlines and monoclines may be underlain by a basal detachment surface merging with blind reverse fault and backthrusts (Fig. 12). The depth of detachment and amount of thrusting still remains unclear. Members of the Lower Triassic shale-sandstone-dolomite or the Upper Permian evaporite-dolomite sequences could serve as gliding surfaces for the subhorizontal motions.

Paleogene thrust tectonics in the Buda Hills has already been suggested by HORUSITZKY (1943). His idea was based on the distribution of Triassic facies. Since the age of Triassic rocks is poorly known and his view was not supported by any structural observations, nappe structures remained questionable. Our study is the first which has provided structural data to support the existence of a detachment fault.

\section{Discussion}

Tectonics, sedimentation, and palaeogeography in the Buda Hills

The occurrence of dextral and reverse faults or folds suggest that deposition of Late Eocene sediments took place in a dextral transpressive regime. Reverse and dextral faults often did not reach the surface during Eocene time, but their propagation induced the growth of antiforms during sedimentation. Tectonic movement initiated the steepening of slopes and beds, slope-parallel extension of layers by boudinage, extension shears and faults. Tectonic instability of slopes led to the formation of gravity flows supplying the basin (Figs. 13, 14). Except for these mobile regions, "quiet" carbonate sedimentation persisted on top of some antiforms, on narrow plateaux. These limestones directly overlie the basement and show no redeposition. Tectonic uplift resulted locally in submarine, or subaerial erosion with karstification. Nevertheless, the general trend is subsidence, and during the deposition of the Buda Marl
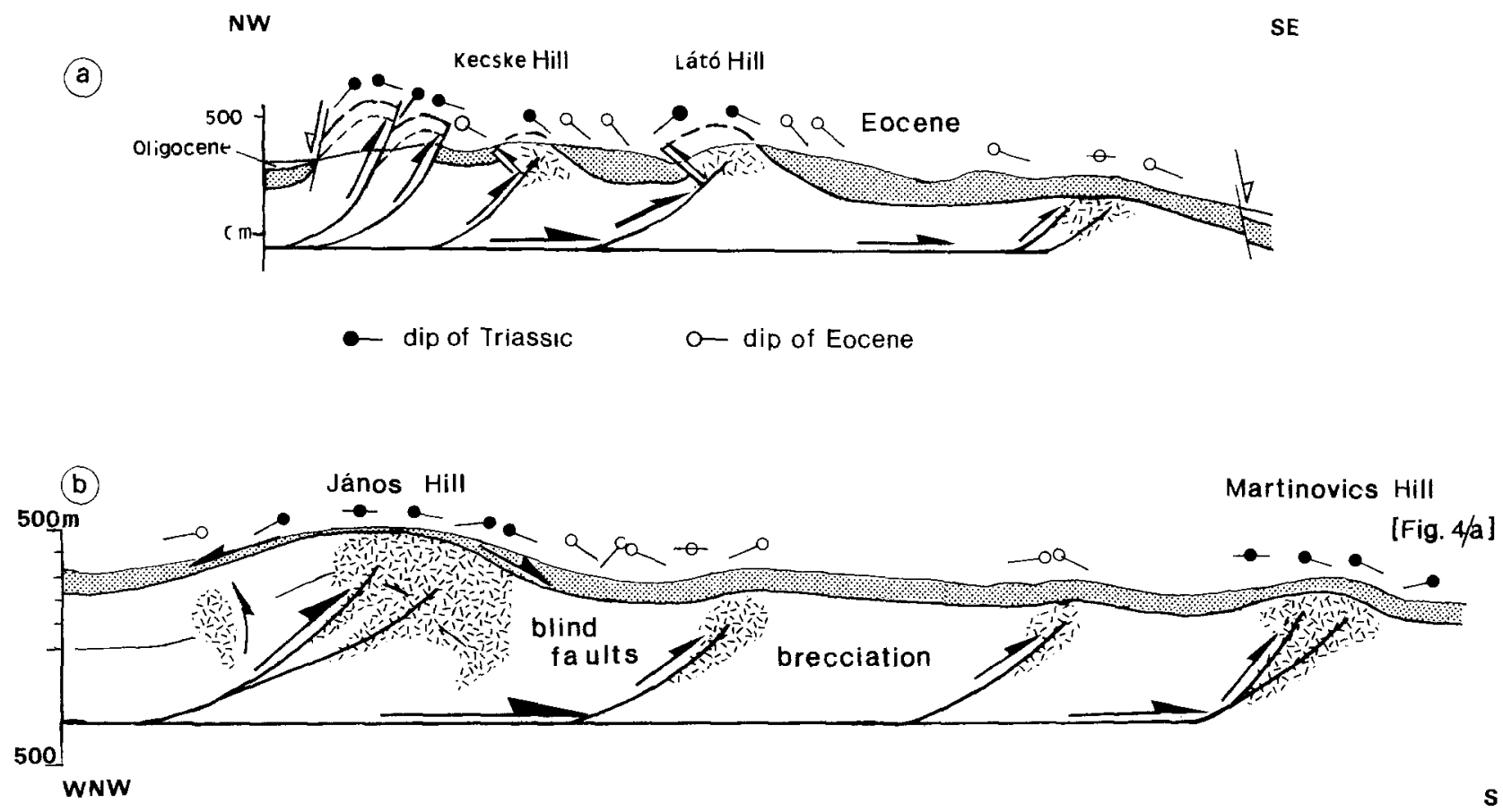

Fig. 12. Cross sections through the Buda imbricate zone. (a) shows reverse faults and backthrusts propagated through Eocene sediments; this section reflects the post-Eocene evolution, too. (b) Fault-propagation folds underlain by blind reverse faults. For locations see Fig. 2. 
even the highest elevations subsided below sea level (Figs. 13a, 14c).

The hinge zone of the highest antiform extending from Budaörs through János Hill to Róka Hill closely approaches the Buda Line. The existence of an actively deforming antiform provides a meaningful explanation for Late Eocene and Early Oligocene palaeogeography
(Figs. 13, 14). During the Late Eocene this hinge marks the extension of the rapidly subsiding eastern bathyal basins, tectonic uplift of the western side of the antiform accommodating the subsidence.

During earliest Oligocene the uplift of the western flank of the János Hill antiform resulted in erosion, while at the eastern side the Tard Clay basin was iso-

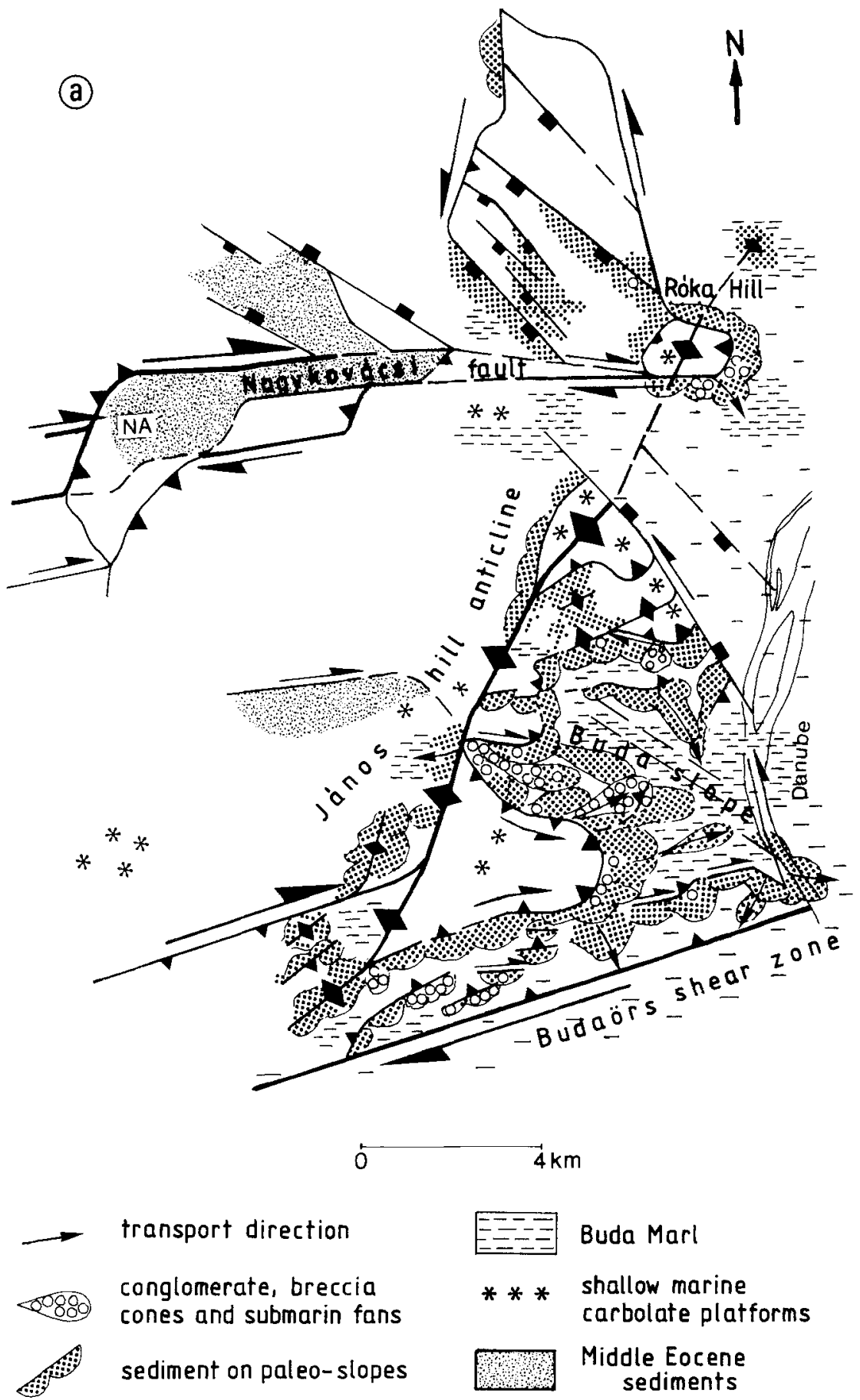

Fig. 13. Tectono-sedimentary model of the Buda Hills. (a) Middle Eocene in the Nagykovácsi depression and Upper Eocene in rest of the Buda Hills. (b) Early Oligocene scenario. 
lated and became anoxic with a specialized endemic biota (Figs. 13b, 14d) (NAGYMAROSY, 1983; BÁLDI, 1986).

The coeval nearshore Hárshegy Sandstone was deposited on the western side of the antiform, while the uppermost Tard Clay and bathyal Kiscell Clay were deposited to the east. BÁLDI \& NAGYMAROSI (1976) suggested the possibility of reefs along the Buda Line which protected the eastern basin from the massive influx of coarse clastics. The existence of a reduced carbonate platform is shown by carbonate turbidites and olistoliths in the Tard Clay (VARGA, 1982, 1985; KECSKEMÉTI \& VARGA, 1985). Our observations suggest that a similar submarine barrier was situated along the hinge zone of the actively deforming János Hill antiform.

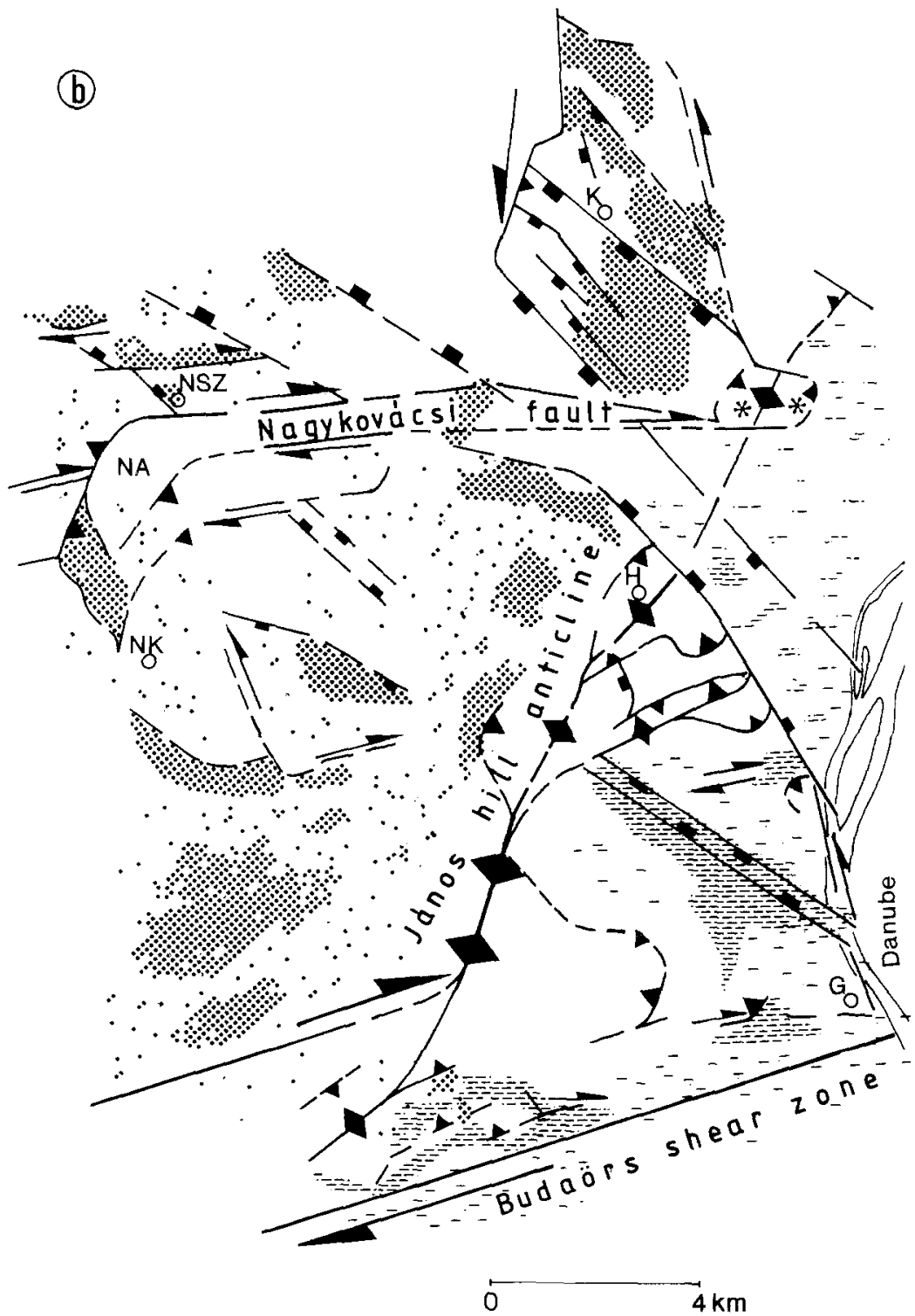

Hárshegy Sandstone (known/inferred)

Upper Tard Clay (known/inferred) 


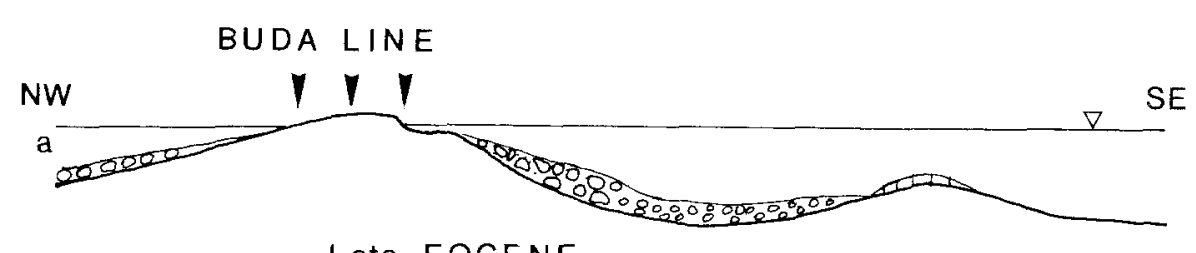

Late EOCENE

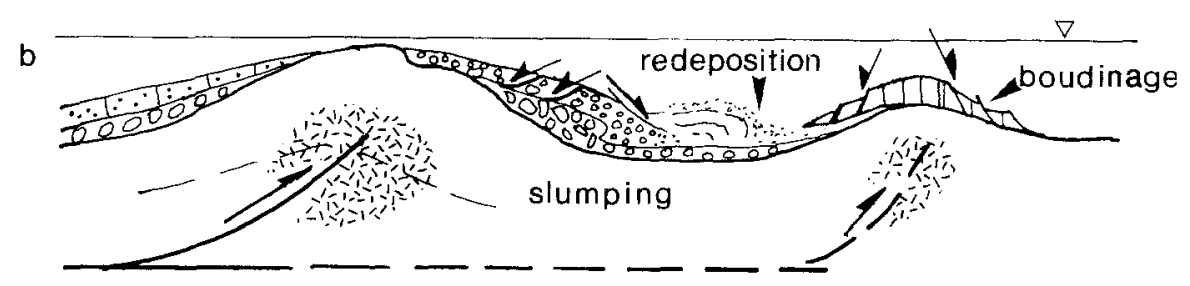

Tard Clay
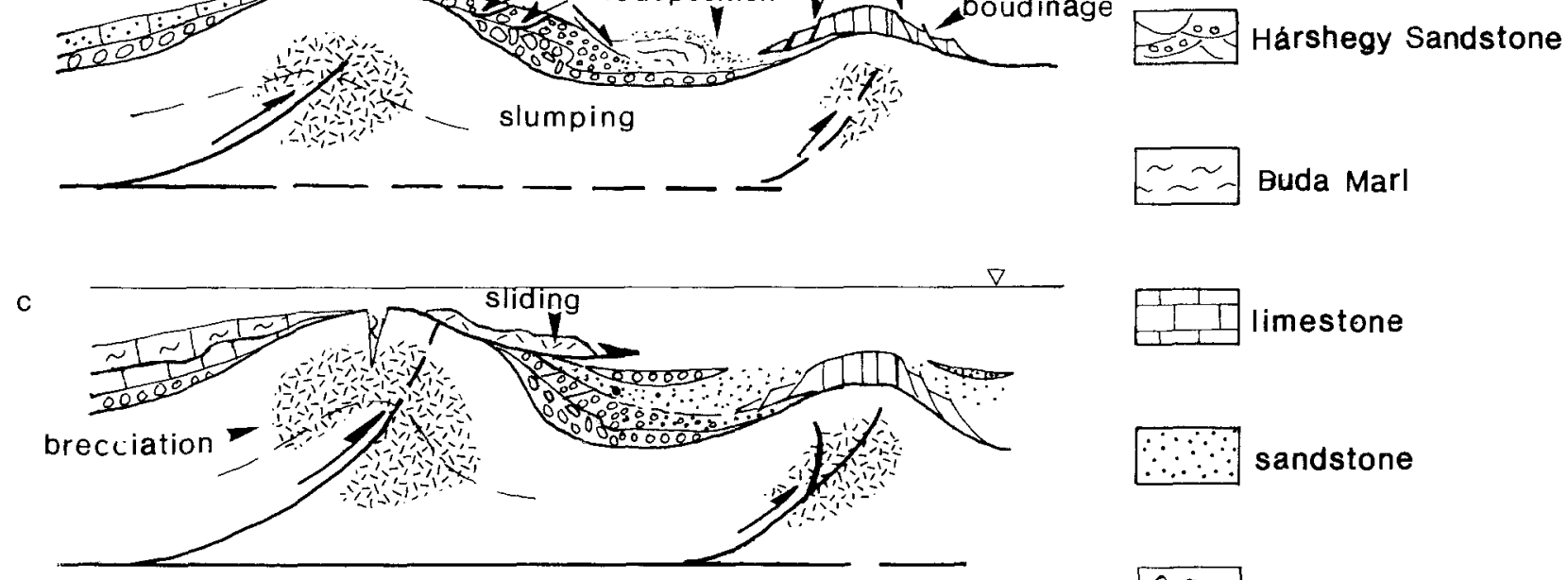

$\because \because \because$ sandstone

Early OLIGOCENE

d

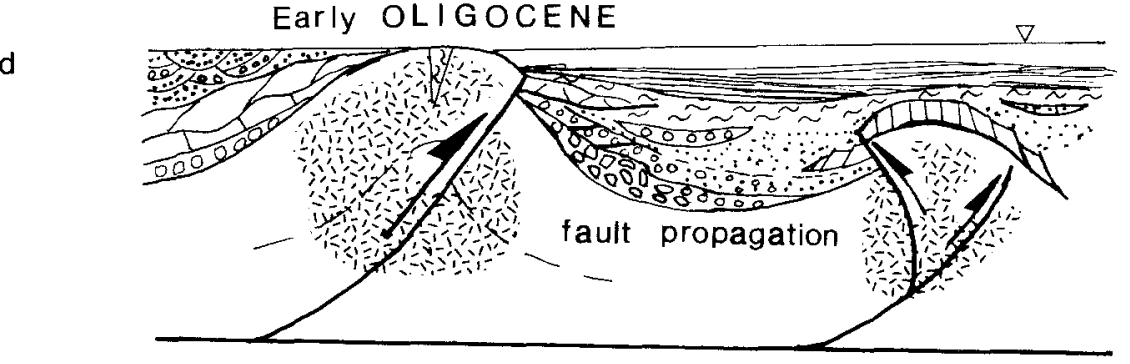

$\left[\begin{array}{lll}0 & 0 & 0 \\ 0 & 0 & 0\end{array}\right]$ conglomerate

Fig. 14. Progressive steepening of slopes and related (re)sedimentation due to reverse fault propagation in a hypothetical section. The Buda Line probably represents a submarine barrier on top of the highest antiform.

Working model of Middle-Late Eocene in the Bakony Unit

The well-studied example of the Buda Hills leads us to suggest a general tectono-sedimentary working model for the Bakony Unit, despite the scarcity of data about synsedimentary tectonics (Fig. 15). First, we can observe a similar micro-fault pattern in quarries everywhere in the Bakony Unit (BERGERAT et al., 1984 and unpublished data; DUDKO, 1990, pers. comm.). WNWESE trending synsedimentary normal faults controlled the deposition of an Upper Eocene slope apron conglomerate at Nyergesújfalu (FODOR et al., 1990b). The large Middle Eocene breccia wedge in the alluvial fan of the Mány basin (FÁY-TÁTRAY, 1984) was probably bordered by a strike-slip fault. Northwestward thicken- ing of a conglomerate body overlying bauxites near Halimba was interpreted as being bordered by NEtrending normal faults (MINDSZENTY et al., 1988); our alternative interpretation is a sedimentary wedge in front of an antiform. These examples suggest that a uniform structural-sedimentological pattern of the Bakony Unit was probably established in the Middle Eocene, while the Buda Hills are certainly of Late Eocene age.

\section{Role of the structures in the escape tectonics of the Bakony Unit}

The dextral shear zone of the Budaörs represents the south-easternmost Palaeogene outcrop of the Bakony Unit. The approx. $10 \mathrm{~km}$-wide zone, which extends to 


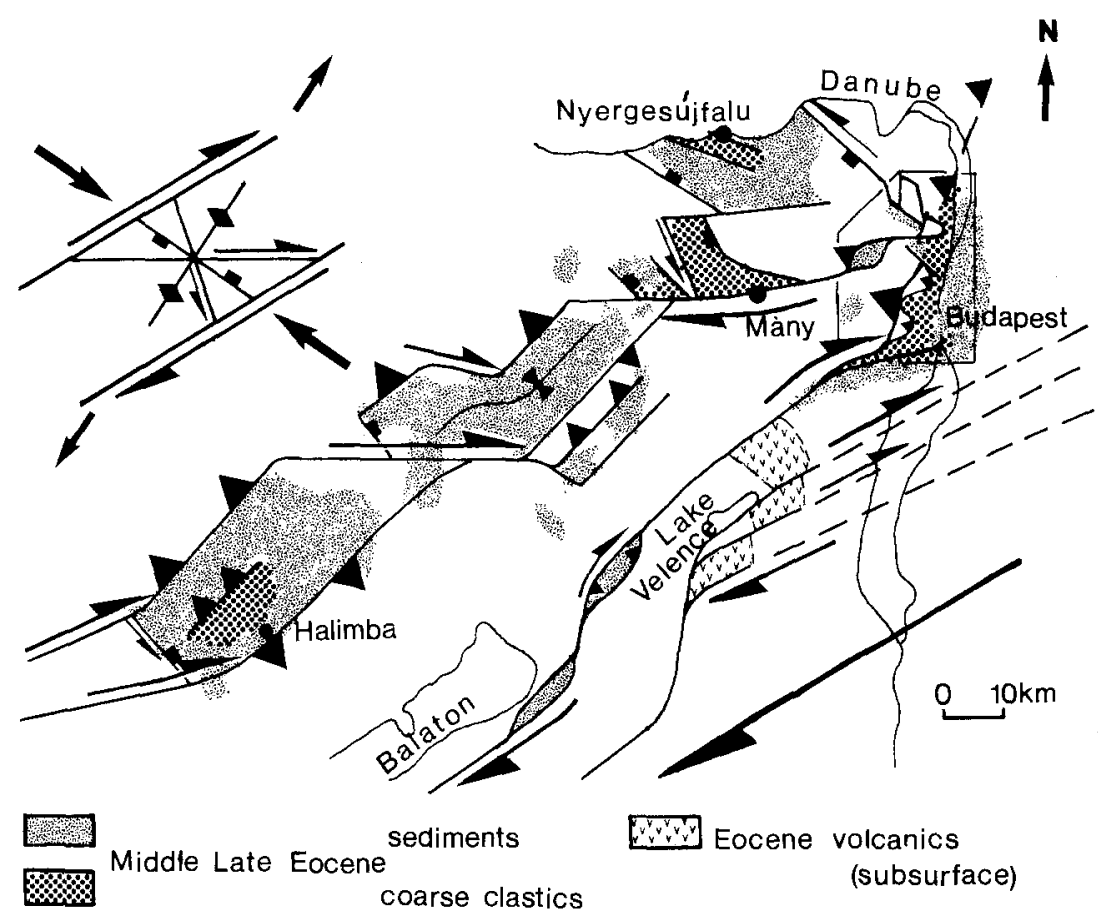

Fig. 15. Tentative model for Middle to Late Eocene sedimentation and tectonics of the Bakony unit. Extension of Eocene sediments is after BÁLDI-BEKE \& BÁLDI (1990, 1991). Structural patterns remain the same during Oligocene time: note the dextral displacement of Eocene volcano-sedimentary bodies in the southeast (after DUDKO, 1988).

the southern border of the Bakony block is covered by Miocene sediments. The stress field and fault pattern in the Buda Hills suggest dextral motion along the southern border fault (Fig. 15). The synsedimentary origin of structures in the Buda Hills suggests that the deformation inside the block and consequently along the border zone, started not later than the Late Eocene. While similar tectono-sedimentary features seem to have been already established in the Middle Eocene, dextral slip of the southern zone of the Bakony Unit may have started at this time.

Similar kinematic conditions persisted during the Oligocene, as proved by fault patterns in the Buda Hills and Northern Bakony (MAROS, 1988). The existence of right-laterally displaced Eocene volcanic and sedimentary bodies close to the southern shear zone represent direct evidence (Fig.. 15) (BALLA et al., 1987; DUDKO, 1988). Dextral displacement of the once contiguous depositional areas continued up to the middle Early Miocene (CsONTOS et al., 1992).

Between the Middle Eocene and Early Miocene, the conferred structural pattern is consistent with dextral slip along the southern border fault zone of the Bakony Unit. These structural data support the continental escape model. While the Bakony seems to be characterized only by dextral faults, the escape movement affected the whole North-Pannonian block, as suggested by BALLA $(1984,1988 a, b)$. The synsedimentary na- ture of the structures suggest initiation of motions in the Middle Eocene.

Palaeomagnetic data indicate $35^{\circ}$ counterclockwise rotation, both for the Bakony Unit and Buda Hills just after the Late Paleogene-Early Miocene tectonic events (MÁRTON, 1985, and pers. comm.). Compensating for this rotation, the original maximum palaeostress axes pointed NNW-SSE during the Late Eocene-Oligocene. This direction is in good agreement with the kinematicdynamic directions determined for the collision of Europe and the Apulian microplate (BERGERAT, 1987; PLATT et al., 1989). This collision can be related to a new cycle of convergence between Africa and Europe starting at the boundary of Early and Middle Eocene (DEWEY, 1990). The beginning of the rapid shortening conspicuously coincides with the start of sedimentation and escape tectonics of the Bakony unit.

\section{Conclusions}

Sedimentological analysis demonstrates that the Upper Eocene sequence of the Buda Hills was mainly deposited on steep palaeoslopes. Sedimentological structures and sediment deformation suggest that slopes were underlain by actively deforming structures in the basement. Tectonic measurements prove that Eocene and Oligocene-Early Miocene structures were formed 
in the same stress field, the latter structures generally reactivating the former ones. The separation of a probable Eocene movement is possible only by a combination of sedimentological and tectonic observations.

Deposition of Late Eocene sediments took place in a dextral transpressive regime. Synsedimentary antiforms were situated above dextral reverse faults of a positive flower structure, or were located on frontal and lateral culmination walls of fault-propagation anticlines.

The structural pattern and direction of stress axes strongly suggest dextral motion along the southern border zone of the Bakony unit. The synsedimentary origin of the structures supports that dextral motion and the escape tectonics started in Middle Eocene times. This dextral motion and the continental escape were a direct response to continental collision between the European plate and the Adrian promontory.

\section{Acknowledgements}

Special thanks are due to Prof. T. Báldi, who introduced us to the intricacies of sedimentation in the Buda Hills. We are grateful for the field comments and advices of F. Surlyk (Copenhagen), H. Reading (Oxford) and M. Kováč (Bratislava). We are very grateful for stimulating remarks of A. Nagymarosy, Z. Balla (both Budapest) and Ph. Ott d'Estevou (Paris) during our studies. We thank F. Bergerat for use of her unpublished tectonic data and J. Angelier (both Paris) for permitting us to use his stress analysis computer program.

O. Sztanó and $Z$. Balla have read an earlier draft of the manuscript and provided many useful comments. Z. Balla and R. Wiedemann translated the Russian and German abstracts, respectively. L. Csontos, J. Wilson, and A.H.F. Robertson kindly helped with improving the manuscript.

\section{References}

ANGELIER, J. (1984): Tectonic analysis of fault data sets. - J. Geophys. Res., 89, 5835-5848.

BÁLDI, T. (1982): Mid-Tertiary tectonic and palaeogeographic evolution of the Carpathian-East Alpine-Pannonian system. - Öslénytani Viták (Discussiones Palaeontologicae), 28, 79155, Budapest. (In Hungarian with English abstract).

- (1986): Mid-Tertiary Stratigraphy and Paleogeographic Evolution of Hungary. - Akadémiai Kiadó, Budapest, 201 pp.

- \& BÁLDI-BEKE, M. (1985): The evolution of the Hungarian Paleogene basins. - Acta Geol. Hungarica, 28, 5-28, Budapest.

-, HoRVÁTH, M., NAgYMarosy, A. \& VARGa, P. (1984): The Eocene-Oligocene boundary in Hungary. The Kiscellian Stage. - Acta Geol. Hungarica, 27, 41-65, Budapest.

-, HORVÁTH, M., KÁZMÉR, M., MONOSTORI, M., NAGYMarosy, A. \& VARGA, P. (1983): The Terminal Eocene Events. Field guide to Late Eocene (Priabonian)Early Oligocene (Kiscellian) Profiles of Hungary. - Visegrád Meeting, Department of Geology, Eötvös University, 75 pp.

- \& NAGYMAROSI, A. (1976): Silicification of the Hárshegy Sandstone and its hydrothermal origin. - Földtani Közlöny, 106, 257-275, Budapest. (In Hungarian with English summary).

BÁLDI-BEKE, M. (1972): The nannoplankton of the Upper Eocene bryozoan and Buda marls. - Acta Geol. Hungarica, 16, 211-228, Budapest.

- (1984): The nannoplankton of the Transdanubian Palaeogene formations. - Geologica Hungarica, Series Palaeontologica, 43, 1-307, Budapest.

-, \& BÁLDI, T. (1990): Subsidence history of the Bakony Eocene basin in W-Hungary. - Általános Földtani Szemle, 25, 83-118, Budapest. (In Hungarian with English abstract).

- \& - (1991): Palaeobathymetry and palaeogeography of the Bakony Eocene Basin in Western Hungary. Palaeogeography, Palaeoclimatology, Palaeoecology, 88, 25-52, Amsterdam.

BALLA, Z. (1988a): Clockwise paleomagnetic rotations in the Alps in the light of the structural pattern of the Transdanubian Range (Hungary). - Tectonophysics, 145, 277-292.

- (1988b): On the origin of the structural pattern of Hungary. - Acta Geol. Hungarica, 31, 53-63, Budapest.
- \& DUDKO, A. (1989): Large-scale Tertiary strike-slip displacements recorded in the structure of the Transdanubian Range. - Geophysical Transactions, 35, 3-63, Budapest.

- \&-(1991): Folded Oligocene beds in Budapest. - Acta Geol. Hungarica, 33, 31-42, Budapest.

-, TÁTRAI, M. \& DudKO, A. (1987): A Közép-Dunántúl fiatal tektonikája földtani és geofizikai adatok alapjàn. (Young tectonics of Central Transdanubia, based on geological and geophysical data). - Annual Report of the Eötvös L. Geophys. Inst. of Hungary for 1986, 74-94, Budapest (in Hungarian).

BERgERAT, F. (1987): Stress fields in the European platform at the time of Africa-Eurasia collision. - Tectonics, 6, 99-132.

-, GEYSSANT, J. \& KÁZMÉR, M. (1983): Une tectonique synsédimentaire originale du Miocène moyen des environs de Budapest, marqueur de l'extension du bassin pannonien. - C.R. Acad. Sci. Paris, Sér. II, 296, 1275-1278.

-, - \& LEPVRIER, C. (1984): Etude de la fracturation dans le bassin pannonien: mécanismes et étapes de sa création. Annales Soc. Géol. du Nord, 103, 265-272, Lille.

BODA, J. \& MONOSTORI, M. (1972): Contributions to the formation of the "Buda Marl“ (Paleogene). - Öslénytani Viták (Discussiones Palaeontologicae), 20, 63-70, Budapest. (In Hungarian with English abstract).

Bordet, P., Montenat, C. H., OtT D'Estevou, P. H. \& VACHARD, D. (1982): La "Bréche rouge" de Carboneras: Un olistostrome volcano-sédimentaire tortonien (Cordillères bétiques orientales, Espagne). - Mémoires Géol. de l'Univ. Dijon, 7, 285-300.

Burke, K. \& ŞENGÖR, A.M.C. (1986): Tectonic escape in the continental crust. - In: Barazangi, M. (editor): Reflection Seismology: The Continental Crust. American Geophysical Union, Geodynamics Series, 14, 41-51.

BUTLER, R.W.H. (1982): The terminology of structures in thrust belts. - J. Structural Geol., 4, 239-245.

CSONTOS, L., TARI, G., Bergerat, F. \& FOdOR, L. (199l): Evolution of the stress fields in the Carpatho-Pannonian area during the Neogene. - Tectonophysics 199, 73-91.

DEWEY, J., F. (1990): Evolution of the Mediterranean region from 220-0 Ma. - Paleomap \& G.S. Tethys Meeting, Univ. P. \& M. Curie, Paris, p. 22. 
DuDKo, A. (1988): Tectonics of the Balatonfö-Velence area (Hungary). - Földtani Közlöny, 118, 207-218, Budapest. (In Hungarian with English summary).

FÁY-TÁTRAY, M. (1984): Contribution to the lithology of the reworked clastic dolomite complex of the Southern Gerecse forelands (Transdanubia, Hungary). - Annales Univ. Sci. Budapest., Sect. Geol., 24, 151-166.

FODOR, L., CSONTOS, L., BERGERAT, F., KÁZMÉR, M., KOVÁC, M., TARI, G., NAGYMAROSY, A., MindSZENTY, A. \& FÁYTÁTRAY, M. (1990a): Evolution géodynamique du bloc Nord-Pannonien durant le Tertiaire. - Téthys Information, Lettre 5, 5, Paris.

-, SzTanó, O. \& VARGA, P. (1990b): Upper Eocene tectonically influenced slope apron deposits at Nyergesújfalu. Manuscript, Eötvös Univ., Dept. Geol. (In Hungarian).

- \& KÁzMÉR, M. (1989): Clastic and carbonate sedimentation in an Eocene strike-slip basin at Budapest. - In: Császár, G. (editor): Tenth IAS Regional Meeting, Excursion Guidebook, Hungarian Geol. Institute, Budapest, 227- 259.

FOGARASI, A. (1991): Evidence for carbonate slope environment during Late Eocene time in Budapest, Hungary. - EUG VI Meeting, Strasbourg. Terra Abstracts 3, 346.

HEMPTON, M.R. \& DUNNE, L.A. (1984): Sedimentation in pullapart basins: active examples in eastern Turkey. - J. Geol., 92, 513-530.

HoRUSITZKY, F. (1943): A Budai-hegység hegyszerkezetének nagy egységei. (Principal tectonic units of Buda Hills). Beszámoló a M. Kir. Földtani Intézet Vitaüléseinek Munkálatairól, 5, 238-251, Budapest. (In Hungarian).

HoRvÁTH, E. \& TARI, G. (1987): Middle Triassic volcanism in the Buda Mountains. - Annales Univ. Sci. Budapest., Sect. geol. 27, 3-16.

JASKÓ, S. (1948): A new cave in the Mátyás Hill near Budapest. - Relationes Annuae Instituti Geologici Publici Hungarici, B) Disputationes 1948, 133-155, Budapest (In Hungarian with English summary)

KÁZMÉR, M. (1984): Paleogene history of the Periadriatic Lineament: A Hungarian point of view. -27 th International Geological Congress, Moscow, Abstracts III, 254.

- (1985): Microfacies pattern of the Upper Eocene limestones at Budapest, Hungary. - Annales Univ. Sci. Budapest, Sect. Geol., 25 (1983), 139-152.

- \& KovÁCS, S. (1985): Permian-Paleogene paleogeography along the eastern part of the Insubric-Periadriatic lineament system: Evidence for continental escape of the BakonyDrauzug unit. - Acta Geol. Hungarica, 28, 71-84, Budapest.

KECSKEMÉTI, T. \& VARGA, P. (1985): Contribution au problème de la limite Eocène/Oligocène sur la base des grands foraminifères étudiés dans les nouvelles coupes. - Földtani Közlöny, 115, 233--247. (In Hungarian with French abstract).

KovÁcs, S. (1983): Major tectonic outline of the Alps. Általános Földtani Szemle, 18, 77-155, Budapest. (In Hungarian with English abstract).

KubovicS, I., SZABÓ, CS. \& GÁl-SÓlymos, K. (1989): A new occurrence of lamprophyre in the Buda Mountains, Hungary. - Acta Geol. Hungarica, 32, 149-168, Budapest.

MAGYARI, Á. (1991a): Late Eocene sedimentation and tectonics in Odvas Hill, Budapest, Hungary. - EUG VI Meeting, Strasbourg. Terra Abstracts, 3, 250.

- (1991b): Késó-eocén üledékképzödés és tektonika kapcsolata a Budaörsi-hegyekben. [Relations between Late Eocene tectonics and sedimentation in the Budaörs Hills]. M. Sc. Thesis, Dept. of Geol., Eötvös Univ., Budapest, 95 pp. (In Hungarian)

MAROS, G. Y. (1988): Tectonic survey in the Vitány-vár area, Hungary. - Annual Report of the Hungarian Geological Institute of 1986, 295-310, Budapest.
MARTINIS, B. (1977): Studio geologico della area maggiormento colpita del terremoto friulano del 1976. - Rivista Italiana di Paleontologia e Stratigrafia, 83, Milano.

MÁrTON, E. (1985): Tectonic implications of paleomagnetic results for the Carpatho-Balkan and adjacent areas. - In: Dixon, J.E. \& Robertson, A.H.F. (editors): Geological Evolution of the Eastern Mediterranean. Geol. Soc. Special Publication, 17, 645-654.

MINDSZENTY, A. (1984): The lithology of some Hungarian bauxites. A contribution to the palaeogeographic reconstruction. - Acta Geologica Hungarica, 27, 441-455, Budapest.

-, Szintai, M., Tóth, K., Szantner, F., NaGy, T., Gellai, M. \& BAROSS, G. (1988): Sedimentology and depositional environment of the Csabpuszta bauxite (Paleocene/Eocene) in the South Bakony Mts. (Hungary). - Acta Geol. Hungarica, 31, 339-370, Budapest.

MONOSTORI, $\dot{M}$. (1965): Paläoökologische und Faziesuntersuchungen an den Obereozän-Schichten in der Umgebung von Budapest. - Annales Univ. Sci.- Budapest., Sect. Geol., 8, 139-149.

- (1987): Terminal Eocene and Early Oligocene events in Hungary: changes of ostracod assemblages. - Acta Geol. Hungarica, 30, 99-110, Budapest.

NÁDOR, A. (1992): A Budai-hegység paleokarszt-jelenségei és fejlödéstörténetük. [Palaeokarsts of the Buda Hills and their evolution.] Ph. D. Thesis. Department of Geology, Eötvös University, Budapest, 178 p. (In Hungarian).

NAGYMAROSY, A. (1983): Mono- and duospecific nannofloras in Early Oligocene sediments of Hungary. - Proceedings of the Koninklijke Nederlandse Akademie van Wetenschappen, Series B, 86, 273-283.

PALOTÁs, K. (1991): A Tétényi-fennsík szedimentológiája és tektonikája a szarmatában. (Sedimentology and tectonics of the Tétény Plateau in the Sarmatian). - M. Sc. Thesis, Dept. Geol., Eötvös Univ., Budapest, 100 pp. (In Hungarian).

Platt, J. P., Behrmann, J.H., Cunningham, P.C., Dewey, J.F., Helman, M., PARISh, M., ShePley, M.G., WAllis, S. \& WESTON, P.J. (1989): - Kinematics of the Alpine arc and the motion history of Adria. Nature, 337, 158-161, London.

PLATT, J. P., \& VISSERS, R.L.M. (1980): Extensional structures in anisotropic rocks. - J. Struct. Geol., 2, 397-410.

RAtschbacher, L., Frisch, W., Neubauer, F., Schmid, S.M. \& NeugebauER, J. (1989): Extension in compressional orogenic belts: The Eastern Alps. - Geology, 17, 404-407.

ROYDEN, L.H. \& BÁLDI, T. (1988): Early Cenozoic tectonics and paleogeography of the Pannonian and surrounding regions. In: Royden, L.H. \& Horváth, F. (editors): The Pannonian Basin. A study in Basin Evolution. American Association of Petroleum Geologists Memoir, 45, 1-16, Tulsa.

ŞEnGÖR, A.M.C., GÖRÜR, N. \& SAROGLU, F. (1985): Strikeslip faulting and related basin formation in zones of tectonic escape: Turkey as a case study. - In: Biddle, K.T. \& ChristieBlick, N. (editors): Strike-slip Deformation, Basin Formation and Sedimentation. Society of Economic Paleontologists and Mineralogists Special Publication, 37, 227-264, Tulsa.

SuPPE, J. (1983): Geometry and kinematics of fault-bend folding. - Am. J. Sci., 283, 684-721, New Haven.

SzöTs, E. (1956): L'Eocène (Paléogène) de la Hongrie. Geologica Hungarica, Series Geologica, 9, 1-320, Budapest.

SZTRÁKOŚ, K. (1987): Les Foraminifères bartoniens et priaboniens de couches à "Tritaxia szaboi" de Hongrie et essai de reconstitution paléogéographique de la Montagne Centrale de Hongrie au Bartonien at au Priabonien. - Cahiers de Micropaléontologie, N. S., 2, 5-37, Paris. 
TAPPONNIER, P. (1977): Evolution tectonique du système alpin en Méditerranée: poinçonnement et écrasement rigideplastique. - Bull. Soc. Géol. France, (7) 19, 437-460.

-, Peltzer, G., Le Dain, A. Y., ARMuo, R. \& CobBold, P. (1982): Propagating extrusion tectonics in Asia: new insights from simple experiments with plasticine.-Geology, 10, 611-616.

TARI, G. (1992): Neogene transpression in the Northern Thrust Zone, Mecsek Mts., Hungary. - Ann. Univ. Sci. Budapest., Sect. Geol. (in press).

VARGA, P. (1982): The lower marine member of the Tard Clay: Its age on the faunal evidence of allodapic limestone beds. Földtani Közlöny, 112, 177-184, Budapest. (In Hungarian with English abstract).
- (1985): Turbiditic limestone intercalations of the Buda Marl and Tard Clay - Öslénytani Viták (Discussiones Palaeontologicae), 31, 93-99, Budapest. (In Hungarian with English abstract).

WALDRON, J.W.F., TURnER, D. \& STEVENS, K.M. (1988): Stratal disruption and development of melange, western Newfoundland: effect of high fluid pressure in an accretionary terrain during ophiolite emplacement. - J. Structural Geol., 10, 861-873.

WEIN, Gy. (1977): A Budai-hegység tektonikája. [Tectonics of Buda Hills.] - Spec. Papers Hung. Geol. Survey, 76 p, 4 coloured maps. (In Hungarian). 